\title{
Perancangan Alat Material Handling untuk Mereduksi Tingkat Risiko Cedera Tulang Belakang Operator pada Aktivitas Pemindahan Semen di Toko Bangunan X
}

\author{
Material Handling Equipment Design to Reduce the Risk of Worker's Musculoskeletal \\ DisordersforCement Displacement Activity at Toko Bangunan X
}

\author{
Lydia Liestiana Karliman, Elty Sarvia \\ Program Studi Teknik Industri - Universitas Kristen Maranatha \\ Email: 1ydia.liestiana@gmail.com, eltysarvia@yahoo.com
}

\begin{abstract}
Abstrak
Pekerja memindahkan semen dari mobil ke gudang secara berulang, dengan postur tubuh kurang baik, dan tanpa menggunakan alat bantu material handling. Hal ini menyebabkan pekerja merasa kelelahan dan sakit pada beberapa bagian tubuhnya, sehingga tidak masuk kerja keesokan harinya.Tujuan penelitian ini adalah menganalisis risiko musculoskeletal disorders (MSDs) yang mungkin dialami pekerja. Pengolahan data menggunakan kuesioner SOFI (Swedish Occupational Fatigue Inventory), kuesioner NBM (Nordic Body Map), Image analysis, REBA (Rapid Entire Body Assesment), dan RWL (Recommended Weight Limit).Kuesioner SOFI menginformasikan pekerja merasa ketidaknyamanan fisik, kurang energi, dan kelelahan fisik. Kuesioner NBM menginformasikan beberapa bagian tubuh yang dirasa sakit setelah melakukan aktivitas pemindahan semen. Metode REBA menyatakan dari 12 skenario yang ada, terdapat 4 skenario dengan tingkat risiko tinggi, 4 skenario dengan tingkat risiko menengah, dan 4 skenario dengan tingkat risiko rendah. Metode RWL menyatakan aktivitas pengangkatan semen tersebut memiliki risiko MSDs dilihat dari nilai lifting index.Penulis memberikan usulan alat material handling untuk mereduksi tingkat risiko MSDs yang mungkin dialami pekerja. Hasil evaluasi usulan menyatakan penurunan tingkat risiko yang dialami pekerja. REBA usulan menyatakan hanya terdapat 1 skenario dengan tingkat risiko menengah dan 11 skenario sisanya dengan tingkat risiko rendah. Hasil RWL usulan menyatakan penurunan nilai lifting index yang cukup signifikan.
\end{abstract}

Kata kunci: SOFI (Swedish Occupational Fatigue Inventory), NBM (Nordic Body Map), REBA (Rapid Entire Body Assesment), RWL (Recommended Weight Limit).

\begin{abstract}
The worker always moves cement from car to the warehouse repeatedly, poor posture, and without material handling equipment. It caused the worker felt fatigue and pain in several parts of his body, so the worker missed work the next day. This research is to analyze the risk of worker's musculoskeletal disorders (MSDs). This research used SOFI (Swedish Occupational Fatigue Inventory), NBM (Nordic Body Map), image analysis, REBA (Rapid Entire Body Assesment), and RWL (Recommended Weight Limit). SOFI informed that the worker felt physical discomfort, lack of energy, and physical exertion. NBM informed that his body was pain. REBA informed that from 12 scenarios, there were 4 scenarios of high risk, 4 scenarios of medium risk, and 4 scenarios of low risk. RWL method showed that acitivity contain risk of MSDs from lifting index. Writer gives material handling equipment proposal to reduce the worker's risk of MSDs. The evaluation showed reduction of worker's risk of MSDs. REBA proposal showed that there was only one scenario with medium risk and 11 scenarios with low risk. $R$ WL proposal showed the significant lower lifting index.
\end{abstract}

Keywords: SOFI (Swedish Occupational Fatigue Inventory, NBM (Nordic Body Map), REBA (Rapid Entire Body Assesment), RWL (Recommended Weight Limit).

\section{Pendahuluan}

Seiring dengan meningkatnya pertumbuhan perekonomian di Indonesia, membuat pembangunan juga semakin meningkat. Untuk memenuhi kebutuhan yang semakin meningkat tersebut banyak orang membuka usaha di bidang bahan bangunan, salah satunya dalam bentuk toko. Salah satu hal penting yang harus dipenuhi dari toko bangunan adalah memiliki pekerja untuk mengangkat 
barang-barang yang dibutuhkan pembeli, termasuk barang berat. Barang yang terlalu berat jika diangkat oleh manusia secara terus-menerus dengan jarak yang cukup jauh serta postur yang kurang baik memiliki risiko cedera tulang belakang (musculoskeletal disorders). Musculoskeletal disorders (MSDs) adalah masalah ergonomi yang sering dijumpai ditempat kerja, khususnya yang berhubungan dengan kekuatan dan ketahanan manusia dalam melakukan pekerjaannya. Masalah tersebut lazim dialami oleh para pekerja yang melakukan gerakan yang sama dan berulang secara terus menerus.Rasa sakit (capek atau cepat lelah ini karena prosedur kerja dan perancangan fasilitas kerja yang kurang ergonomis, kondisi ini akan memberikan dampak pada hasil produktivitas kerja yang tidak optimal selain berpotensi cidera pada bagian tubuh tertentu akibat aktivitas kerja yang tidak seimbangan dengan keterbatasan manusia (susihono, 2009). Postur tubuh yang tidak seimbang dan berlangsung dalam jangka waktu lama dapat mengakibatkan stress pada bagian tubuh tertentu, yang biasa disebut dengan "postural stress". Banyak penelitian telah dilakukan mengenai penilaian postur kerja seperti dalam industri tekstil pada operator Stasiun Two for One Bawah (Evita,2017), operator Stasiun Two for One Atas (Evita,2019), dalam industri perakitan mobil di India (Srikanth P, 2015), operator industri porselen (Ahmadi, 2015), operator mesin bubut (Ingale, 216), dan industri kecil-menengah yang memproduksi makanan pada operator penanganan material di Sumatera Utara (I Rizkya, 2018). Evaluasi postur kerja di industri kecil dapat disimpulkan bahwa terdapat peluang adanya gangguan muskuloskeletal pada tingkat sedang hingga tinggi. Untuk itu perlu rekomendasi penerapan intervensi ergonomis dengan pengetahuan yang tepat diantara para pekerja dan pengetahuan kesehatan postur, implementasi dam pemantauan undang-undang untuk mengurangi rasa sakit karena gangguan muskuloskeletal (Ansari,2014).

Penelitian ini mengamati operator yang melakukan kegiatan pengangkatan barang berat yaitu pemindahan semen secara manual. Pekerja melakukan pengangkatan semen dari mobil ke gudang maupun sebaliknya secara berulang. Frekuensi pengangkatan semen dari mobil ke gudang berkisar antara 50-160 sak, sedangkan frekuensi pengangkatan dari gudang menuju ke mobil hanya berkisar antara 10-20 sak semen. Banyaknya frekuensi pengangkatan semen ini menjadi dasar untuk memfokuskan pengamatan pada aktivitas pengangkatan semen saja karena hal ini menjadi salah satu faktor utama penyebab keluhan musculoskeletal pada pekerja. Keluhan musculoskeletal adalah keluhan pada bagian-bagian otot skeletal yang dirasakan oleh seseorang mulai dari keluhan sangat ringan sampai sangat sakit. Apabila otot menerima beban statis secara berulang dan dalam waktu yang lama, akan dapat menyebabkan keluhan berupa kerusakan pada sendi, ligament, dan tendon. Keluhan hingga kerusakan inilah yang biasanya diistilahkan dengan keluhan MusculoskeletalDisorders (MSDs) atau cedera pada sistem (Tarwaka dkk, 2004).

Aktivitas pengangkatan semen dilakukan pekerja secara manual dan tanpa bantuan alat material handling. Pekerja perlu mengangkat semen dari mobil satu persatu dan kemudian menuju gudang dan meletakkannya dalam satu tumpukan dengan tinggi 10 sak semen. Kendala yang sering terjadi adalah jika telah terlalu banyak mengangkat barang berat, pekerja akan merasa kelelahan dan sakit di beberapa bagian tubuh sehingga tidak akan masuk kerja keesokan harinya. Pengangkatan barang berat yang tidak dilakukan dengan benar tentu akan menimbulkan resiko cedera atau kecelakaan kerja. Tingginya tingkat cedera atau kecelakaan kerja selain merugikan secara langsung yaitu sakit yang diderita oleh pekerja, juga akan berdampak buruk terhadap kinerja perusahaan yaitu berupa penurunan produktivitas perusahaan, baik melalui beban biaya pengobatan yang cukup tinggi dan juga ketidakhadiran pekerja serta penurunan kualitas kerja. Penelitian ini bertujuan untuk menganalisis keluhan pekerja terkait dengan berat barang yang dibawa ditinjau dari hasil kuesioner SOFI dan Nordic Body Map, menganalisis kondisi postur kerja pekerja ditinjau dari segi analisis metode REBA (Rapid Entire Body Assesment) dan risiko cedera tulang belakang pekerja sekarang ditinjau dari segi analisis metode RWL (Recommended Weight Limit), serta mengusulkan alat bantu yang dapat membantu pekerja terhindar dari risiko cedera. 


\section{Tinjauan Pustaka}

2.1. Ergonomi

Istilah "ergonomi" berasal dari bahasa latin yaitu ERGON (KERJA) dan NOMOS (HUKUM ALAM) dan dapat didefinisikan sebagai studi tentang aspek-aspek manusia dalam lingkungan yang ditinjau secara anatomi, fisiologi, psikologi, engineering, manajemen dan desain atau perancangan. Ergonomi berkenaan pula dengan optimasi, efisiensi, kesehatan, keselamatan dan kenyamanan manusia di tempat kerja, di rumah dan tempat rekreasi. Di dalam ergonomi dibutuhkan studi tentang sistem dimana manusia, fasilitas kerja dan lingkungannya saling berinteraksi dengan tujuan utama yaitu menyesuaikan suasana kerja dengan manusianya (Nurmianto, 2004).

\subsection{Manual Material Handling}

Manual material handling atau manual handling adalah suatu kegiatan memindahkan yang dilakukan oleh satu pekerja atau lebih dengan melakukan kegiatan pengangkatan, penurunan, mendorong, menarik, mengangkut, dan memindahkan barang. (Suhardi, 2008).

Aktivitas manual handling merupakan sebuah aktivitas memindahkan beban oleh tubuh secara manual dalam rentang waktu tertentu. Occupational Safety and Health Administration (OSHA) mengklasifikasikan kegiatan manual material handling menjadi lima, yaitu:

1. Mengangkat/menurunkan (lifting/lowering). Mengangkat adalah kegiatan memindahkan barang ke tempat yang lebih tinggi yang masih dapat dijangkau oleh tangan. Kegiatan lainnya adalah menurunkan barang.

2. Mendorong/menarik (pushing/pulling). Kegiatan mendorong adalah kegiatan menekan berlawanan arah tubuh dengan usaha yang bertujuan untuk emindahkan obyek. Kegiatan menarik kebalikan dengan mendorong.

3. Memutar (twisting). Kegiatan memutar merupakan kegiatan MMH yang merupakan gerakan memutar tubuh bagian atas ke sat atau dua sisi, sementara tubuh bagian bawah berada dalam posisi tetap. Kegiatan memutar ini dapat dilakukan dalam keadaan tubuh diam.

4. Membawa (carrying). Kegiatan membawa merupakan kegiatan memegang atau mengambil barang dan memindahkannya. Berat benda menjadi berat total pekerja.

5. Membawa (holding). Memegang obyek saat tubuh berada dalam posisi diam (statis). Dalam rangka untuk menciptakan suasana kerja yang aman dan sehat maka perlu adanya suatu batasan angkat untuk operator.

\subsection{Biomekanika Kerja}

Biomekanika adalah ilmu yang menggunakan hukum-hukum fisika dan mekanika teknik untuk mendeskripsikan gerakan pada bagian tubuh (kinematik) dan memahami efek gaya dan momen yang terjadi pada tubuh (kinetik) (Chaffin dkk, 2006). Biomekanika juga merupakan keilmuan yang mengombinasikan hukum-hukum fisika dan konsep-konsep teknik dengan pengetahuan dari keilmuan biologi dan perilaku manusia (Chaffin dkk, 2006)

\subsection{Kuesioner SOFI}

Kelelahan pekerja dapat diukur dengan metoda subjektif yang relatif cepat hasilnya dan tidak memerlukan waktu dan biaya yang besar, serta relatif mudah dalam mengintrepretasikan hasilnya. Salah satu instrument subjektif kelelahan yang banyak digunakan adalah Swedish Occupational Fatigue Index (SOFI). Instrumen ini merupakan instrumen pengukuran kelelahan dan kantuk yang pertama kali dikembangkan oleh Ahsberg (1998). SOFI memiliki lima dimensi pengukuran yaitu lack of energy, physical exertion, physical discomfort, lack of motivation dan sleepiness. Kelima dimensi ini merupakan penjabaran lebih lanjut dari kelelahan fisik (physical exertion dan physical discomfort) dan kelelahan mental (lack of motivation dan sleepiness). Dimensi lack of energy mewakili kualitas dari kelelahan yang dirasakan secara umum oleh subjek. Gambar dibawah ini adalah model kelelahan dan kantuk berdasarkan SOFI. 


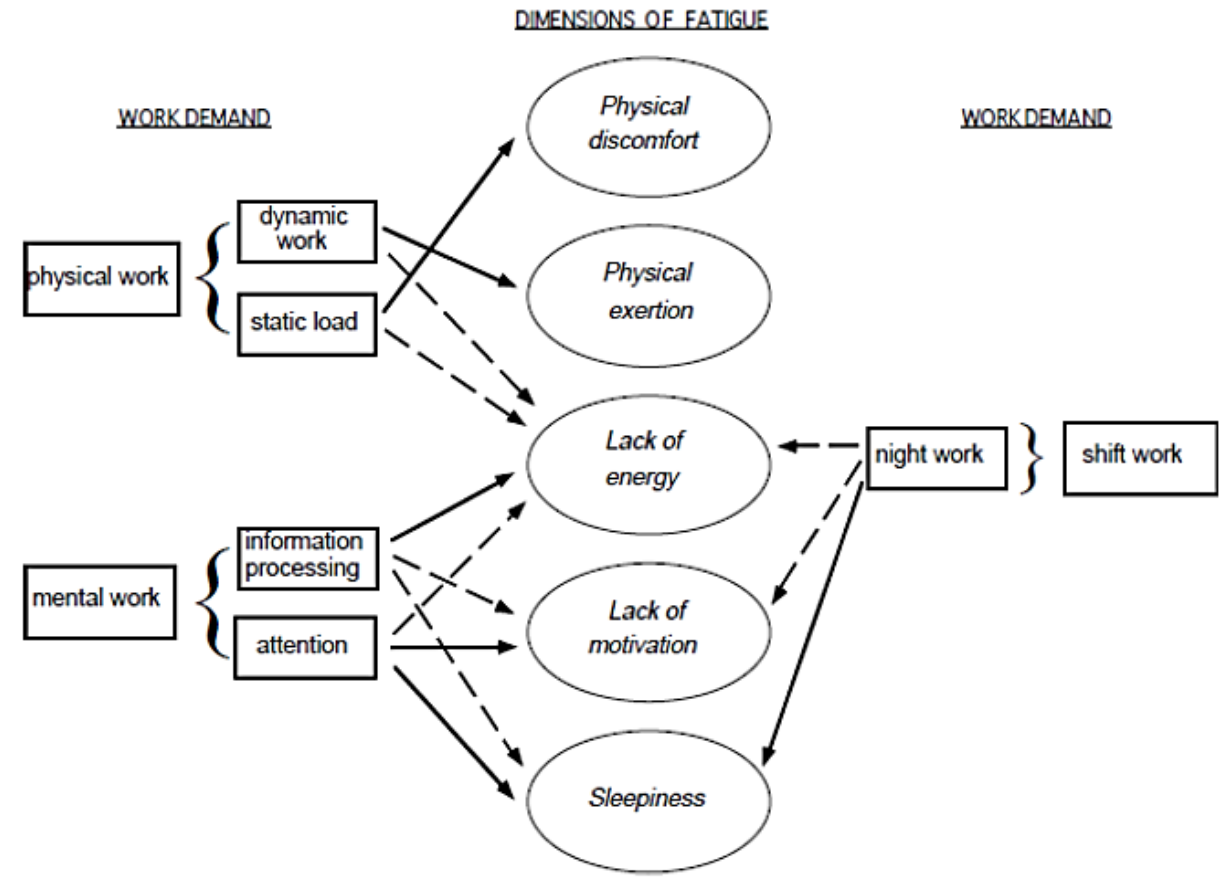

Gambar 1. Dimensi Fatigue SOFI (Ahsberg, 1998)

Beban kerja dapat berasal faktor fisik, mental, dan adanya shift kerja. Ketiga faktor ini membentuk lima dimensi dari kelelahan yang dijabarkan dalam 25 poin pernyataan. Tiap subjek diminta untuk menilai kondisi diri secara subjektif mulai dari skala 0 hingga 6 . Skala 0 berarti tidak terasa dan skala 6 berarti pernyataan tersebut sangat dirasakan dan sesuai dengan kondisi subjek.

\begin{tabular}{|c|c|c|}
\hline No & Dimensi & Poin pernyataan (skala 0-6) \\
\hline 1 & Lack of energy & $\begin{array}{l}\text { Overworked } \\
\text { Worn out } \\
\text { Exhausted } \\
\text { Spent } \\
\text { Drained }\end{array}$ \\
\hline 2 & Physical exertion & $\begin{array}{l}\text { Sweaty } \\
\text { Breathing heavily } \\
\text { Palpitations } \\
\text { Warm } \\
\text { Out of breath }\end{array}$ \\
\hline 3 & Physical discomfort & $\begin{array}{l}\text { Tense muscles } \\
\text { Stiff joints } \\
\text { Numbness } \\
\text { Hurting } \\
\text { Aching }\end{array}$ \\
\hline 4 & Lack of motivation & $\begin{array}{l}\text { Uninterested } \\
\text { Passive } \\
\text { Listless } \\
\text { Indifferent } \\
\text { Lack of concern }\end{array}$ \\
\hline 5 & Sleepiness & $\begin{array}{l}\text { Sleepy } \\
\text { Falling asleep } \\
\text { Drowsy } \\
\text { Yawning } \\
\text { Lazy }\end{array}$ \\
\hline
\end{tabular}

Gambar 2. Poin pertanyaan SOFI 


\subsection{Nordic Body Map}

Nordic Body Map merupakan salah satu metode pengukuran subyektif untuk mengukur rasa sakit otot para pekerja (Wilson and Corlett, 1995). Kuesioner Nordic Body Map merupakan salah satu bentuk kuesioner checklist ergonomi.

Pengisian kuesioner Nordic Body Map ini bertujuan untuk mengetahui bagian tubuh dari pekerja yang terasa sakit sebelum dan sesudah melakukan pekerjaan pada stasiun kerja.

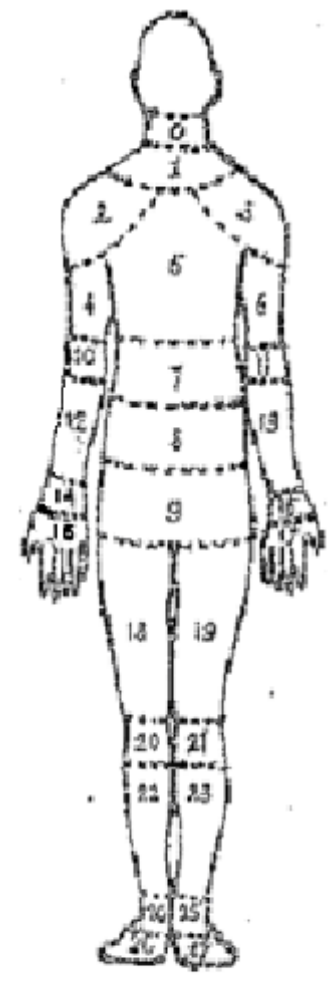

\begin{tabular}{|c|c|c|c|c|c|}
\hline \multirow[t]{2}{*}{ NO } & \multirow[t]{2}{*}{ JENIS KELUHAN } & \multicolumn{4}{|c|}{$\begin{array}{r}\text { TINGKAT } \\
\text { KELUHAN }\end{array}$} \\
\hline & & $\mathrm{A}$ & $\mathrm{B}$ & $\mathrm{C}$ & $\mathrm{D}$ \\
\hline 0 & Sakit/kaku di leher bagian atas & & & & \\
\hline 1 & Sakit/kaku di leher bagian bawah & & & & \\
\hline 2 & Sakit di bahu kiri & & & & \\
\hline 3 & Sakit di bahu kanan & & & & \\
\hline 4 & Sakit pada lengan atas kiri & & & & \\
\hline 5 & Sakit di punggung & & & & \\
\hline 6 & Sakit pada lengan atas kanan & & & & \\
\hline 7 & Sakit pada pinggang & & & & \\
\hline 8 & Sakit pada bokong & & & & \\
\hline 9 & Sakit pada pantat & & & & \\
\hline 10 & Sakit pada siku kiri & & & & \\
\hline 11 & Sakit pada siku kanan & & & & \\
\hline 12 & Sakit pada lengan bawah kiri & & & & \\
\hline 13 & Sakit pada lengan bawah kanan & & & & \\
\hline 14 & Sakit pada pergelangan tangan kiri & & & & \\
\hline 15 & Sakit pada pergelangan tangan kanan & & & & \\
\hline 16 & Sakit pada tangan kiri & & & & \\
\hline 17 & Sakit pada tangan kanan & & & & \\
\hline 18 & Sakit pada paha kiri & & & & \\
\hline 19 & Sakit pada paha kanan & & & & \\
\hline 20 & Sakit pada lutut kiri & & & & \\
\hline 21 & Sakit pada lutut kanan & & & & \\
\hline 22 & Sakit pada betis kiri & & & & \\
\hline 23 & Sakit pada betis kanan & & & & \\
\hline 24 & Sakit pada pergelangan kaki kiri & & & & \\
\hline 25 & Sakit pada pergelangan kaki kanan & & & & \\
\hline 26 & Sakit pada kaki kiri & & & & \\
\hline 27 & Sakit pada kaki kanan & & & & \\
\hline
\end{tabular}

Keterangan : A: Tidak sakit, B: Agak sakit, C: Sakit, D: Sakit sekali

Gambar 3. Nordic Body Map

\subsection{Musculoskeletal System}

Keluhan musculoskeletal adalah keluhan pada bagian-bagian otot skeletal yang dirasakan oleh seseorang mulai dari keluhan sangat ringan sampai keluhan sangat sakit. Apabila otot menerima beban statis berulang-ulang dan dalam waktu yang lama, akan dapat menyebabkan keluhan berupa kerusakan pada sendi, ligamen, dan tendon.

Secara garis besar, keluhan pada otot dapat dikelompokkan menjadi dua, yaitu:

a. Keluhan sementara (reversible), yaitu keluhan otot yang terjadi pada saat otot menerima beban statis. Namun keluhan itu akan segera hilang apabila pembebanan dihentikan.

b. Keluhan menetap (persistent), yaitu keluhan otot yang bersifat menetap. Walaupun pembebanan kerja telah dihentikan, namun rasa sakit pada otot terus berlanjut.

\subsection{Metode Pengukuran Manual Handling REBA}

Rapid Entire Body Assessment (REBA) merupakan sebuah metode yang digunakan untuk menilai tingkat risiko dari sebuah postur kerja. REBA dikembangkan oleh Sue dan Hignett dan dikenalkan pertama kali kepada publik pada tahun 2000. Pengembangan metode ini didasarkan pada beberapa metode assessment ergonomika sebelumnya seperti NIOSH Lifting Equation, Rating of Perceived Exertion, OWAS, Body Part Discomfort Survey dan Rapid Upper Limb Assessment (Sue dan Hignett, 2000). Metode REBA adalah metode observasi dimana pengamat perlu melihat langsung pekerjaan yang dilakukan. Metode REBA perlu dipakai secara terpisah dalam hal pembagian sisi kiri dan kanan tubuh. Setiap analisis REBA menentukan nilai akhir yang akan merepresentasikan tingkat risiko dari pekerja. Pembuat metode REBA menyediakan berbagai macam tingkat usaha perbaikan berdasarkan nilai akhir yang didapat, sebagai berikut: 
- Nilai akhir 1 : tingkat risiko tidak berbahaya dan tidak ada usaha yang perlu dilakukan. (tingkat aksi $=0$ )

- Nilai akhir 2-3 : tingkat risiko rendah dan perbaikan perlu dilakukan jika risiko tersebut diindikasikan oleh informasi lain. (tingkat aksi =1)

- Nilai akhir 4-7 : tingkat risiko menengah dan usaha perbaikan perlu dilakukan. (tingkat aksi = 2)

- Nilai akhir 8-10 : tingkat risiko tinggi dan usaha perbaikan perlu dilakukan segera. (tingkat aksi $=3$ )

- Nilai akhir 11-15 : tingkat risiko sangat tinggi dan tindak lanjut perlu dilakukan sekarang juga. (tingkat aksi $=4$ )

\subsection{Metode Pengukuran Manual Handling RWL}

Recommended Weight Limit merupakan penetapan batas beban yang boleh diangkat oleh pekerja untuk berbagai kondisi pengangkatan. Penetapan batas beban tersebut didasari oleh hasil-hasil penelitian yang menggabungkan pendekatan biomekanika, fisiologi, dan psikofisik. (Waters dkk, 1993).

Terdapat enam faktor yang menentukan besaran RWL, yakni empat faktor yang dipengaruhi sikap saat pengangkatan, satu faktor berkaitan dengan frekuensi pengangkatan, dan satu faktor lagi berkaitan dengan kondisi pegangan benda yang diangkat. enam faktor tersebut disebut sebagai faktor pengali yang menentukan RWL dengan rumusan persamaan berikut (Iridiastadi, 2014):

$\mathrm{RWL}=\mathrm{LC} \times \mathrm{HM} \times \mathrm{VM} \times \mathrm{DM} \times \mathrm{AM} \times \mathrm{FM} \times \mathrm{CM}$

Keterangan:

RWL : Batas beban yang direkomendasikan

LC : Konstanta pembebanan (load constant $)=23 \mathrm{~kg}$

HM : Faktor pengali horizontal (horizontal multiplier) $=25 / \mathrm{H}$

VM : Faktor pengali vertikal (vertical multiplier $)=1-(0.003|\mathrm{~V}-69|)$

DM : Faktor pengali perpindahan (distance multiplier) $=0.82+4.5 / \mathrm{D}$

AM : Faktor pengali asimetrik (asymetric multiplier) $=0.0032 \mathrm{~A}(\mathrm{rad})$

FM : Faktor pengali frekuensi (frequency multiplier)

CM : Faktor pengali pegangan (coupling multiplier)

Dimana :

$H=$ Jarak horizontal posisi tangan yang memegang beban dengan titik pusat tubuh.

$V=$ Jarak vertikal posisi tangan yang memegang beban terhadap lantai

$D=$ Jarak perpindahan beban secara vertikal antara tempat asal sampai tujuan

$A=$ Sudut simetri putaran yang dibentuk antara tangan dan kaki.

\begin{tabular}{ccccccc}
\hline Frekuensi & \multicolumn{2}{c}{$\leq 1$ jam } & \multicolumn{2}{c}{$\leq 2$ jam } & \multicolumn{2}{c}{$\leq$ jam } \\
\cline { 2 - 7 } Liftsmin & $V<75$ & $V \geq 75$ & $V<75$ & $V \geq 75$ & $V<75$ & $V \geq 75$ \\
\hline 0.2 & 1.00 & 1.00 & 0.95 & 0.95 & 0.85 & 0.85 \\
0.5 & 0.97 & 0.97 & 0.92 & 0.92 & 0.81 & 0.81 \\
1 & 0.94 & 0.94 & 0.88 & 0.88 & 0.75 & 0.75 \\
2 & 0.91 & 0.91 & 0.84 & 0.84 & 0.65 & 0.65 \\
3 & 0.88 & 0.88 & 0.79 & 0.79 & 0.55 & 0.55 \\
4 & 0.84 & 0.84 & 0.72 & 0.72 & 0.45 & 0.45 \\
5 & 0.80 & 0.80 & 0.60 & 0.60 & 0.35 & 0.35 \\
6 & 0.75 & 0.75 & 0.50 & 0.50 & 0.27 & 0.27 \\
7 & 0.70 & 0.70 & 0.42 & 0.42 & 0.22 & 0.22 \\
8 & 0.60 & 0.60 & 0.35 & 0.35 & 0.18 & 0.18 \\
9 & 0.52 & 0.52 & 0.30 & 0.30 & 0.00 & 0.15 \\
10 & 0.45 & 0.45 & 0.26 & 0.26 & 0.00 & 0.13 \\
11 & 0.41 & 0.41 & 0.00 & 0.23 & 0.00 & 0.00 \\
12 & 0.37 & 0.37 & 0.00 & 0.21 & 0.00 & 0.00 \\
13 & 0.00 & 0.34 & 0.00 & 0.00 & 0.00 & 0.00 \\
14 & 0.00 & 0.31 & 0.00 & 0.00 & 0.00 & 0.00 \\
15 & 0.00 & 0.28 & 0.00 & 0.00 & 0.00 & 0.00 \\
$>15$ & 0.00 & 0.00 & 0.00 & 0.00 & 0.00 & 0.00 \\
\hline
\end{tabular}


Keterangan V pada tabel diatas dari $75 \mathrm{~cm}$ diganti menjadi $69 \mathrm{~cm}$ untuk orang Indonesia.

\begin{tabular}{|c|c|c|}
$\begin{array}{c}\text { Coupling } \\
\text { Type }\end{array}$ & $\begin{array}{c}\text { Coupling Multiplier } \\
\mathrm{V}<30 \text { inches } \\
(75 \mathrm{~cm})\end{array}$ & $\begin{array}{c}\mathrm{V}>30 \text { inches } \\
(75 \mathrm{~cm})\end{array}$ \\
\hline Good & 1.00 & 1.00 \\
\hline Fair & 0.95 & 1.00 \\
\hline Poor & 0.90 & 0.95 \\
\hline
\end{tabular}

Gambar 5. Faktor pengali pegangan (Waters dkk, 1993)

Untuk Coupling Multiplier (CM) adalah :

1. Kriteria Good, adalah :

- Kontainer atau Box merupakan design optimal, pegangan bahannya tidak licin.

- Benda yang didalamnya tidak mudah tumpah.

- Tangan dapat dengan nyaman meraih box tersebut.

2. Kriteria Fair, adalah :

- Kontainer atau Box tidak mempunyai pegangan.

- Tangan tidak dapat meraih dengan mudah.

3. Kriteria Poor, adalah :

- Box tidak mempunyai Handle/pegangan.

- Sulit dipegang (Licin, Tajam, dll).

- Berisi barang yang tidak stabil, (Pecah, Jatuh, Tumpah, dll).

- Memerlukan sarung tangan untuk mengangkatnya.

NIOSH mengusulkan penilaian anam atau tidaknya aktivitas pengangkatan didasarkan atas Lifting Index (LI). LI dirumuskan sebagai perbandingan antara batas beban yang direkomendasikan untuk diangkat terhadap beban yang seharusnya diangkat. batas beban yang direkomendasikan diangkat dipilih dari nilai terkecil di antara $\mathrm{RWL}_{\text {awal }}$ dan $\mathrm{RWL}_{\text {akhir. }}$ Oleh karena itu, rumusan LI adalah:

$\mathrm{LI}=$ Bobot beban aktual / min $\left\{\mathrm{RWL}_{\mathrm{awal}}, \mathrm{RWL}_{\mathrm{akhir}}\right\}$

Rekomendasi yang diberikan adalah sebagai berikut (Iridiastadi, 2014):

- Jika LI $\leq 1$, maka pekerjaan tersebut aman

- $\quad$ Jila $\mathrm{LI}<\mathrm{LI} \leq 3$, maka pekerjaan tersebut mungkin berisiko

- $\quad$ Jika LI > 3, maka pekerjaan tersebut berisiko

\section{Metodologi Penelitian}

Tahapan awal adalah mengidentifikasi keluhan berdasarkan kuesioner SOFI dan NBM. Kuesioner SOFI sebagai alat ukur kelelahan umum secara subjektif yang mengidentifikasikan kelelahan mental dan kelelahan fisik pekerja sebelum dan sesudah melakukan pekerjaannya. Terdapat 5 faktor yang terkait dengan kelelahan itu sendiri, yaitu kelelahan fisik, ketidaknyamanan fisik, kurang energi, kurang motivasi, dan kantuk. Setiap faktor tersebut diwakili oleh 5 buah ekspresi. Terdapat total 35 ekspresi yang harus diisi oleh pekerja terkait dengan apa yang dirasakannya. Jangkauan nilai yang diberikan adalah dari 0 (tidak sama sekali) sampai 6 (sangat sekali). Pengumpulan data kuesioner SOFI ini perlu dilakukan sebelum dan setelah melakukan aktivitas, yang pada penelitian ini dilakukan pada saat:

- Sebelum pekerja melakukan pekerjaan mengangkat 50 sak semen dari mobil ke gudang.

- Setelah pekerja melakukan pekerjaan mengangkat 50 sak semen dari mobil ke gudang.

- Sebelum pekerja melakukan pekerjaan mengangkat 100 sak semen dari mobil ke gudang.

- Setelah pekerja melakukan pekerjaan mengangkat 100 sak semen dari mobil ke gudang 
Nordic Body Map merupakan kuesioner berupa peta tubuh yang berisikan data bagian tubuh yang dikeluhkan oleh para pekerja. Menurut Tarwaka and Sudiajeng (2004), dengan melihat dan menganalisis peta tubuh (NBM) dapat diestimasi jenis dan tingkat keluhan otot skeletal yang dirasakan pekerja. Kuesioner ini juga merupakan penilaian rasa sakit secara subjektif, yang diisi sendiri oleh pekerja berdasarkan tingkat rasa sakit yang dirasakan pada saat sebelum dan setelah melakukan aktivitas pengangkatan semen. Terdapat total 28 bagian tubuh yang diperkirakan mengalami rasa sakit yang harus diisi oleh pekerja. jangkauan nilai yang diberikan adalah dari 1 (tidak sakit), 2 (agak sakit), 3 (sakit), dan 4 (sangat sakit). Pengumpulan data nordic body map ini juga perlu dilakukan sebelum dan setelah melakukan aktivitas yang sama dengan SOFI. Setelah itu dilakukan perekaman postur kerja pekerja tersebut diambil dalam bentuk foto. Foto postur tersebut kemudian digunakan sebagai bahan untuk analisis menggunakan metode REBA (Rapid Entire Body Assesment). Tahapan selanjutnya adalah data hasil kuesioner SOFI dan NBM akan diolah secara statistika deskriptif. Pengolahan data dengan metode REBA dilakukan dengan menggunakan software Ergofellow yang dimulai dengan melakukan penilaian postur kerja untuk skenario 1 - 12 yang dilakukan dengan cara penilaian neck, trunk, legs, load, upper arm, lower arm, wrist, coupling, activity. Pengolahan dengan metode REBA ini hanya dilakukan pada satu sisi tubuh pekerja karena posisi tubuh bagian kanan dan kiri pekerja sama pada saat melakukan pekerjaannya sehingga cukup satu bagian tubuh saja yang perlu dilakukan penilaian dan analisis. Adapun pengamatan yang dilakukan dalam penganalisaan postur kerja dengan menggunakan metode REBA terdiri dari 12 skenario, yakni:

1. Posisi mengangkat barang dari mobil (Skenario 1)

2. Posisi berjalan menuju toko (Skenario 2)

3. Posisi menurunkan barang ke lantai tumpukan pertama (Skenario 3)

4. Posisi menurunkan barang ke lantai tumpukan kedua (Skenario 4)

5. Posisi menurunkan barang ke lantai tumpukan ketiga (Skenario 5)

6. Posisi menurunkan barang ke lantai tumpukan keempat (Skenario 6)

7. Posisi menurunkan barang ke lantai tumpukan kelima (Skenario 7)

8. Posisi menurunkan barang ke lantai tumpukan keenam (Skenario 8)

9. Posisi menurunkan barang ke lantai tumpukan ketujuh (Skenario 9)

10. Posisi menurunkan barang ke lantai tumpukan kedelapan (Skenario 10)

11. Posisi menurunkan barang ke lantai tumpukan kesembilan (Skenario 11)

12. Posisi menurunkan barang ke lantai tumpukan kesepuluh (Skenario 12)

Selanjutnya, pengolahan data dengan menggunakan metode RWL dilakukan untuk skenario 1 sampai dengan skenario 12, kecuali skenario 2 tidak dapat dihitung dikarenakan merupakan skenario saat pekerja berjalan dari mobil menuju gudang. Metode RWL ini hanya dapat digunakan untuk aktivitas pengangkatan saja. Setelah dilakukan perhitungan nilai RWL, kemudian dilakukan perhitungan Lifting Index dengan cara membagi berat beban dengan nilai RWL yang telah didapatkan. Hasil perhitungan lifting index yang telah didapatkan tersebut akan menghasilkan kesimpulan mengenai risiko cedera tulang belakang yang diderita oleh pekerja pada saat melakukan pekerjaan mengangkat barang berat (semen). Setelah dilakukan pengolahan data dengan menggunakan metode REBA dan RWL dilakukan analisis dan usulan terkait dengan kondisi kerja tersebut. 


\section{Pengolahan Data dan Analisis}

\subsection{Pengolahan Data SOFI}

Berikut ini adalah hasil pengolahan kuesioner SOFI guna mengetahui tingkat kelelahan umum (kelelahan fisik dan kelelahan mental) yang dialami oleh pekerja sebelum dan setelah melakukan aktivitas pengangkatan 50 sak dan 100 sak semen.

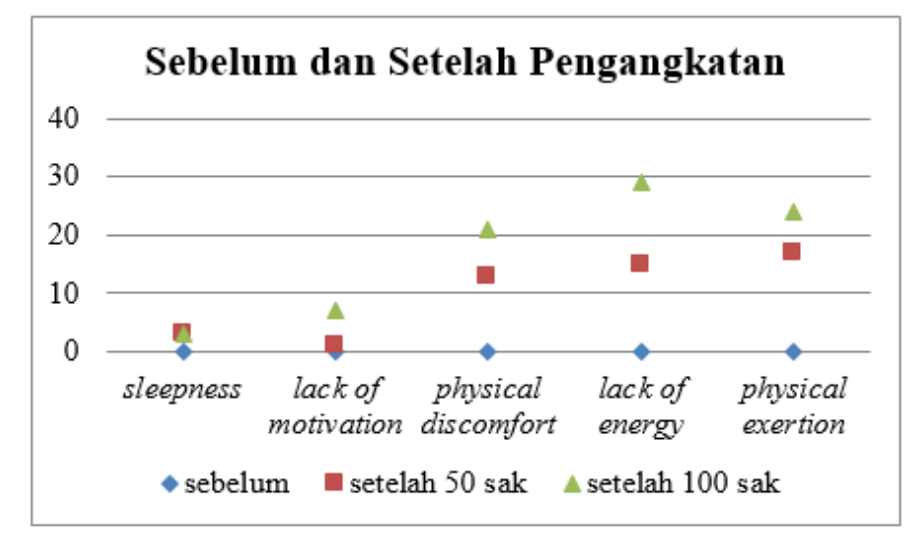

Gambar 6. Grafik SOFI sebelum dan setelah mengangkat semen

Dari grafik di atas, dapat dilihat bahwa ada kenaikan tingkat keluhan yang dirasakan oleh pekerja sebelum dan setelah melakukan aktivitas pengangkatan semen. Sebelum melakukan aktivitas pengangkatan semen, pekerja tidak merasakan keluhan apapun mengenai kondisi kelelahan, baik kelelahan mental maupun kelelahan fisiknya. Setelah melakukan aktivitas pengangkatan semen, pekerja mulai merasakan adanya kelelahan. Kelelahan yang paling dirasakan oleh pekerja adalah kelelahan fisik, yaitu pada faktor physical discomfort (ketidaknyamanan fisik), lack of energy (kurang energi), dan physical exertion (kelelahan fisik).Tingkat kelelahan pekerja meningkat seiring dengan frekuensi pengangkatan semen yang dilakukannya.

\subsection{Pengolahan Data Nordic Body Map}

Dari hasil kuesioner SOFI yang telah diisi secara subjektif oleh pekerja sebelumnya, dapat diketahui bahwa pekerja lebih merasa kelelahan secara fisik dibandingkan dengan kelelahan secara mental. Oleh sebab itu, penulis kemudian menggunakan kuesioner nordic body map untuk mengetahui tingkat keluhan sakit yang dirasakan oleh pekerja pada bagian tubuhnya, baik sebelum maupun setelah melakukan kegiatan penangkatan semen tersebut. 
PERANCANGAN ALAT MATERIAL HANDLING (Lydia L.K., dkk.)

Tabel 1. Hasil Kuesioner Nordic Body Map

\begin{tabular}{|c|c|c|c|c|c|c|c|c|c|c|c|c|c|}
\hline \multirow{3}{*}{ No } & \multirow{3}{*}{ Bagian Tubuh } & \multicolumn{4}{|c|}{ Sebelum } & \multirow{2}{*}{\multicolumn{4}{|c|}{$\begin{array}{c}\text { Setelah } 50 \text { sak semen } \\
\text { Tingkat Keparahan }\end{array}$}} & \multirow{2}{*}{\multicolumn{4}{|c|}{$\frac{\text { Setelah } 100 \text { sak semen }}{\text { Tingkat Keparahan }}$}} \\
\hline & & \multicolumn{4}{|c|}{ Tingkat Keparahan } & & & & & & & & \\
\hline & & 1 & 2 & 3 & 4 & 1 & 2 & 3 & 4 & 1 & 2 & 3 & 4 \\
\hline 1 & Leher Bagian Atas & $\sqrt{ }$ & & & & & $\mathrm{V}$ & & & & & $\sqrt{ }$ & \\
\hline 2 & Leher Bagian Bawah & $\mathrm{V}$ & & & & & $\sqrt{ }$ & & & & & $\sqrt{ }$ & \\
\hline 3 & Bahu Kiri & $\sqrt{ }$ & & & & & $\mathrm{V}$ & & & & & $\sqrt{ }$ & \\
\hline 4 & Bahu Kanan & $\sqrt{ }$ & & & & & $\sqrt{ }$ & & & & & $\sqrt{ }$ & \\
\hline 5 & Lengan Atas Kiri & $\sqrt{ }$ & & & & & & $\sqrt{ }$ & & & & $\sqrt{ }$ & \\
\hline 6 & Lengan Atas Kanan & $\sqrt{ }$ & & & & & & $\sqrt{ }$ & & & & $\sqrt{ }$ & \\
\hline 7 & Punggung & $\sqrt{ }$ & & & & & & $\sqrt{ }$ & & & & & $\sqrt{ }$ \\
\hline 8 & Pinggang & $\sqrt{ }$ & & & & & & $\sqrt{ }$ & & & & & $\mathrm{V}$ \\
\hline 9 & Bokong & $\sqrt{ }$ & & & & $\sqrt{ }$ & & & & & $\sqrt{ }$ & & \\
\hline 10 & Pantat & $\mathrm{V}$ & & & & $\sqrt{ }$ & & & & & $\sqrt{ }$ & & \\
\hline 11 & Siku Kiri & $\sqrt{ }$ & & & & $\sqrt{ }$ & & & & & $\sqrt{ }$ & & \\
\hline 12 & Siku Kanan & $\sqrt{ }$ & & & & $\sqrt{ }$ & & & & & $\mathrm{V}$ & & \\
\hline 13 & Lengan Bawah Kiri & $\sqrt{ }$ & & & & & V & & & & & $\sqrt{ }$ & \\
\hline 14 & Lengan Bawah Kanan & $\sqrt{ }$ & & & & & $\sqrt{ }$ & & & & & $\sqrt{ }$ & \\
\hline 15 & Pergelangan Tangan Kiri & $\sqrt{ }$ & & & & & $\mathrm{V}$ & & & & & $\mathrm{V}$ & \\
\hline 16 & Pergelangan Tangan Kanan & $\sqrt{ }$ & & & & & $\sqrt{ }$ & & & & & $\mathrm{V}$ & \\
\hline 17 & Tangan Kiri & $\mathrm{V}$ & & & & & $\mathrm{V}$ & & & & & $\mathrm{V}$ & \\
\hline 18 & Tangan Kanan & $\mathrm{V}$ & & & & & $\sqrt{ }$ & & & & & $\mathrm{V}$ & \\
\hline 19 & Paha Kiri & $\sqrt{ }$ & & & & & $\mathrm{V}$ & & & & & $\mathrm{V}$ & \\
\hline 20 & Paha Kanan & $\sqrt{ }$ & & & & & $\mathrm{V}$ & & & & & $\mathrm{V}$ & \\
\hline 21 & Lutut Kiri & $\sqrt{ }$ & & & & $\sqrt{ }$ & & & & & $\mathrm{V}$ & & \\
\hline 22 & Lutut Kanan & $\mathrm{V}$ & & & & $\sqrt{ }$ & & & & & $\sqrt{ }$ & & \\
\hline 23 & Betis Kiri & $\sqrt{ }$ & & & & & $\mathrm{V}$ & & & & & $\mathrm{V}$ & \\
\hline 24 & Betis Kanan & $\sqrt{ }$ & & & & & $\mathrm{V}$ & & & & & $\mathrm{V}$ & \\
\hline 25 & Pergelangan Kaki Kiri & $\sqrt{ }$ & & & & $\sqrt{ }$ & & & & & $\mathrm{V}$ & & \\
\hline 26 & Pergelangan Kaki Kanan & $\sqrt{ }$ & & & & $\sqrt{ }$ & & & & & $\mathrm{V}$ & & \\
\hline 27 & Kaki Kiri & $\mathrm{V}$ & & & & & $\mathrm{V}$ & & & & & $\mathrm{V}$ & \\
\hline 28 & Kaki Kanan & $\mathrm{V}$ & & & & & $\mathrm{V}$ & & & & & $\mathrm{V}$ & \\
\hline & Total & 28 & 0 & 0 & 0 & 8 & 16 & 4 & 0 & 0 & 8 & 18 & 2 \\
\hline
\end{tabular}

Keterangan : $1=$ Tidak Sakit $; 2=$ Agak Sakit $; 3=$ Sakit $; 4=$ Sangat Sakit

Dari tabel gabungan hasil kuesioner nordic body map di atas dapat dilihat bahwa sebelum pekerja melakukan aktivitas pengangkatan semen, pekerja tidak merasakan ada keluhan sakit pada bagian tubuh manapun. Seiring dengan meningkatnya frekuensi pengangkatan semen tersebut, meningkat pula tingkat keluhan rasa sakit pekerja pada beberapa bagian tubuhnya tersebut.

\subsection{Pengolahan Data REBA}

Penilaian faktor risiko cedera tulang belakang dilakukan menggunakan tools REBA terhadap setiap skenario yang ada yaitu skenario 1 sampai dengan skenario 12. Dalam pengolahan metode REBA ini, anggota tubuh bagian leher, badan, lengan atas, lengan bawah, pergelangan tangan, dan kaki masing-masing dinilai faktor risikonya melalui sudut-sudut yang telah didapatkan dari hasil penilaian sudut-sudut tubuh dengan menggunakan fitur image analysis pada software ergofellow. 
Tabel 2. Hasil Metode REBA

\begin{tabular}{|c|c|c|c|c|}
\hline Skenario & Kegiatan & $\begin{array}{c}\text { Final } \\
\text { Score }\end{array}$ & $\begin{array}{c}\text { Tingkat } \\
\text { Risiko }\end{array}$ & Keterangan \\
\hline 1 & Mengangkat semen dari mobil & 4 & Menengah & Butuh analisis dan perbaikan segera \\
\hline 2 & Berjalan dari mobil ke gudang & 3 & Rendah & Perbaikan mungkin diperlukan \\
\hline 3 & Menurunkan semen tumpukan satu & 9 & Tinggi & Perlu analisis dan implementasi perbaikan \\
\hline 4 & Menurunkan semen tumpukan dua & 9 & Tinggi & Perlu analisis dan implementasi perbaikan \\
\hline 5 & Menurunkan semen tumpukan tiga & 9 & Tinggi & Perlu analisis dan implementasi perbaikan \\
\hline 6 & Menurunkan semen tumpukan empat & 9 & Tinggi & Perlu analisis dan implementasi perbaikan \\
\hline 7 & Menurunkan semen tumpukan lima & 5 & Menengah & Butuh analisis dan perbaikan segera \\
\hline 8 & Menurunkan semen tumpukan enam & 4 & Menengah & Butuh analisis dan perbaikan segera \\
\hline 9 & Menurunkan semen tumpukan tujuh & 4 & Menengah & Butuh analisis dan perbaikan segera \\
\hline 10 & Menurunkan semen tumpukan delapan & 3 & Rendah & Perbaikan mungkin diperlukan \\
\hline 11 & Menurunkan semen tumpukan sembilan & 3 & Rendah & Perbaikan mungkin diperlukan \\
\hline 12 & Menurunkan semen tumpukan sepuluh & 3 & Rendah & Perbaikan mungkin diperlukan \\
\hline
\end{tabular}

Dari 12 skenario, diketahui terdapat 4 skenario dengan tingkat risiko rendah, 4 skenario dengan tingkat risiko menengah, dan 4 skenario dengan tingkat risiko tinggi. Tingkat risiko tinggi ini disebabkan karena pada proses penurunan semen tumpukan awal, punggung pekerja sangat membungkuk, yang mengakibatkan semakin tingginya risiko cedera tulang belakang yang akan dialami oleh pekerja.

\subsection{Pengolahan Data RWL}

Tujuan dari perhitungan RWL dan Lifting Index ini adalah untuk mengetahui bagaimana pengaruh beban yang dibawa oleh pekerja terhadap risiko cedera tulang belakang atau musculoskeletal disorders.

Tabel 3. Perhitungan RWL dan LI

\begin{tabular}{|c|c|c|c|c|c|c|c|c|c|c|c|}
\hline Skenario & Kondisi & $\mathrm{LC}$ & $\mathrm{Hm}$ & $\mathrm{Vm}$ & $\mathrm{Dm}$ & $\mathrm{Am}$ & $\mathrm{Fm}$ & $\mathrm{Cm}$ & RWL & LI & Keterangan \\
\hline \multirow{2}{*}{1} & Origin & 23 & 1.000 & 0.973 & 0.993 & 1.000 & 0.910 & 0.950 & 19.213 & \multirow{2}{*}{2.602} & \multirow{2}{*}{ mungkin berisiko } \\
\hline & Destination & 23 & 1.000 & 0.949 & 0.993 & 1.000 & 0.910 & 1.000 & 19.725 & & \\
\hline \multirow{2}{*}{3} & Origin & 23 & 1.000 & 0.949 & 0.872 & 1.000 & 0.910 & 1.000 & 17.327 & \multirow{2}{*}{5.816} & \multirow{2}{*}{ berisiko } \\
\hline & Destination & 23 & 0.625 & 0.793 & 0.872 & 1.000 & 0.910 & 0.950 & 8.597 & & \\
\hline \multirow{2}{*}{4} & Origin & 23 & 1.000 & 0.949 & 0.881 & 1.000 & 0.910 & 1.000 & 17.495 & \multirow{2}{*}{5.235} & \multirow{2}{*}{ berisiko } \\
\hline & Destination & 23 & 0.658 & 0.829 & 0.881 & 1.000 & 0.910 & 0.950 & 9.552 & & \\
\hline \multirow{2}{*}{5} & Origin & 23 & 1.000 & 0.949 & 0.893 & 1.000 & 0.910 & 1.000 & 17.729 & \multirow{2}{*}{4.951} & \multirow{2}{*}{ berisiko } \\
\hline & Destination & 23 & 0.658 & 0.865 & 0.893 & 1.000 & 0.910 & 0.950 & 10.100 & & \\
\hline \multirow{2}{*}{6} & Origin & 23 & 1.000 & 0.949 & 0.910 & 1.000 & 0.910 & 1.000 & 18.075 & \multirow{2}{*}{4.662} & \multirow{2}{*}{ berisiko } \\
\hline & Destination & 23 & 0.658 & 0.901 & 0.910 & 1.000 & 0.910 & 0.950 & 10.725 & & \\
\hline \multirow{2}{*}{7} & Origin & 23 & 1.000 & 0.949 & 0.938 & 1.000 & 0.910 & 1.000 & 18.639 & \multirow{2}{*}{4.347} & \multirow{2}{*}{ berisiko } \\
\hline & Destination & 23 & 0.658 & 0.937 & 0.938 & 1.000 & 0.910 & 0.950 & 11.502 & & \\
\hline \multirow{2}{*}{8} & Origin & 23 & 1.000 & 0.949 & 0.993 & 1.000 & 0.910 & 1.000 & 19.725 & \multirow{2}{*}{3.956} & \multirow{2}{*}{ berisiko } \\
\hline & Destination & 23 & 0.658 & 0.973 & 0.993 & 1.000 & 0.910 & 0.950 & 12.640 & & \\
\hline \multirow{2}{*}{9} & Origin & 23 & 1.000 & 0.949 & 1.000 & 1.000 & 0.910 & 1.000 & 19.863 & \multirow{2}{*}{3.857} & \multirow{2}{*}{ berisiko } \\
\hline & Destination & 23 & 0.658 & 0.991 & 1.000 & 1.000 & 0.910 & 0.950 & 12.964 & & \\
\hline \multirow{2}{*}{10} & Origin & 23 & 1.000 & 0.949 & 1.000 & 1.000 & 0.910 & 1.000 & 19.863 & \multirow{2}{*}{3.802} & \multirow{2}{*}{ berisiko } \\
\hline & Destination & 23 & 0.658 & 0.955 & 1.000 & 1.000 & 0.910 & 1.000 & 13.150 & & \\
\hline \multirow{2}{*}{11} & Origin & 23 & 1.000 & 0.949 & 1.000 & 1.000 & 0.910 & 1.000 & 19.863 & \multirow{2}{*}{4.159} & \multirow{2}{*}{ berisiko } \\
\hline & Destination & 23 & 0.625 & 0.919 & 1.000 & 1.000 & 0.910 & 1.000 & 12.022 & & \\
\hline \multirow{2}{*}{12} & Origin & 23 & 1.000 & 0.949 & 1.000 & 1.000 & 0.910 & 1.000 & 19.863 & \multirow{2}{*}{4.329} & herisiko \\
\hline & Destination & 23 & 0.625 & 0.883 & 1.000 & 1.000 & 0.910 & 1.000 & 11.551 & & DenISIKO \\
\hline
\end{tabular}

Dari tabel perhitungan nilai RWL dan LI, diketahui bahwa nilai Lifting Index untuk aktivitas pengangkatan semen tersebut cukup tinggi. Hanya skenario 1 yang memiliki nilai lifting index antara 1 sampai 3, sedangkan skenario lainnya memiliki nilai lifting index di atas 3 . Hal ini berarti aktivitas pengangkatan semen ini merupakan aktivitas yang cukup memiliki risiko cedera tulang belakang. 


\section{Perancangan dan Analisis}

\subsection{Usulan Alat Material Handling}

Gangguan Muskuloskeletal dapat diminimalkan melalui peningkatan teknik, metode kerja, dan fasilitas (Isa H, 2011) . Alternatif alat material handling yang diusulkan oleh penulis berbentuk seperti meja dengan permukaan datar yang difungsikan sebagai alat untuk memindahkan beban. Meja ditopang oleh bantuan hidrolik yangdapat disesuaikan ketinggiannya sesuai dengan kebutuhan dalam aktivitas mengangkat dan memindahkan beban. Hal ini bertujuan agar pada saat melakukan pemindahan beban, postur tubuh pekerja tidak membungkuk terutama pada saat meletakkan beban pada tumpukan bagian bawah. Alat material handling ini dilengkapi dengan roda pada keempat sisi bagian bawahnya sehingga memungkinkan beban dapat dipindahkan dengan mudah dari satu area ke area yang lain. Roda yang ada juga dilengkapi dengan pengunci yang akan memastikan alat ini tidak akan bergerak pada saat beban sedang dinaikkan. Cara penggunaan pengunci roda ini sangat mudah, cukup dengan menginjak bagian yang menonjol tersebut ke bawah, sehingga secara otomatis akan mengganjal roda supaya terkunci dan tidak akan bergerak. Selain itu, diusulkan penggunaan pallet pada alat material handling ini yang bertujuan setelah melakukan aktivitas loading pada alat material handling tersebut nantinya pekerja tidak perlu melakukan aktivitas unloading lagi setelah alat material handling itu sampai digudang karena tumpukan semen digudang disimpan bersama dengan palletnya.

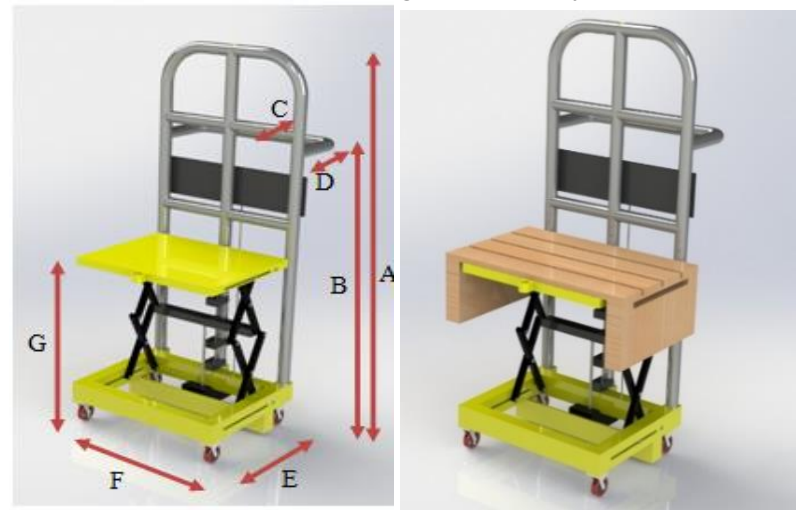

Gambar 7. Alat material handling usulan dengan dan tanpa pallet

Dimensi alat material handling ini disesuaikan dengan dimensi benda yang akan diangkut, dan juga data antropometri sehingga pekerja diharapkan dapat menggunakan alat material handling ini dengan aman dan nyaman.

Tinggi tiang pada bagian belakang alat material handling ini (A) adalah setinggi $142 \mathrm{~cm}$. Ukuran ini dipertimbangkan karena satu sak semen memiliki tinggi $12 \mathrm{~cm}$, sehingga 10 tumpukan semen berarti memiliki tinggi $120 \mathrm{~cm}$. Ditambah dengan tinggi platform, meja platform, dan juga roda sehingga didapatkan tinggi total sebesar $142 \mathrm{~cm}$. Selain mempertimbangkan tinggi tumpukan semen, hal yang juga harus diperhatikan dan dipertimbangkan adalah tinggi tiang pada bagian belakang alat material handling ini tidak menutupi pandangan. Tinggi mata pada posisi berdiri pria (persentil 5) adalah sebesar $147 \mathrm{~cm}$. Hal ini berarti tinggi alat material handling ini tidak menutupi pandangan pada saat digunakan, terutama pada saat pekerja mendorong alat ini ke dalam gudang.

Tinggi pegangan (untuk mendorong alat material handling) pada tiang bagian belakang (B) adalah $124,7 \mathrm{~cm}$. Ukuran ini dipertimbangkan berdasarkan data antropometri tinggi bahu pria (persentil 5). Hal ini bertujuan agar momen gaya pekerja menjadi lebih kecil sehingga tenaga yang dikeluarkan pada saat mendorong alat material handling ini tidak terlalu besar. Penggunaan persentil 5 dimaksudkan agar orang dengan tinggi paling rendah dapat menggunakan alat ini dengan nyaman, sehingga secara tidak langsung orang yang lebih tinggi juga dapat menggunakannya dengan nyaman. Health Safety Executive juga menganjurkan posisi mendorong maupun mengangkat yang paling baik adalah berada di antara pinggul dan bahu. (Sumber: HSE : Manual material handling at work: a brief guide, Health Safety Executive, 2012). 
Diameter pegangan (untuk mendorong alat material handling) pada tiang bagian belakang (C) adalah $4,5 \mathrm{~cm}$. Ukuran ini dipertimbangkan berdasarkan data antropometri diameter genggam pria (persentil 5). Hal ini bertujuan agar pekerja dapat menggenggam pegangan dengan nyaman pada saat mendorong alat material handling tersebut. Penggunaan persentil 5 dimaksudkan agar orang dengan diameter genggam paling kecil dapat menggunakan alat ini dengan nyaman, sehingga secara tidak langsung orang dengan diameter genggam lebih besar juga dapat menggunakannya dengan nyaman.

Jarak pegangan ke tiang bagian belakang alat material handling (D) adalah $18,9 \mathrm{~cm}$. Ukuran ini dipertimbangkan berdasarkan data antropometri panjang tangan pria (persentil 95). Hal ini bertujuan agar pada saat pekerja akan memasukkan tangan untuk mendorong pegangan alat material handling tersebut tidak mengenai tiang bagian belakang. Penggunaan persentil 95 dimaksudkan agar orang dengan panjang tangan paling panjang dapat menggunakan alat ini dengan nyaman, sehingga secara tidak langsung orang dengan panjang tangan lebih pendek juga dapat menggunakannya dengan nyaman.

Lebar platform (E) alat material handling ini adalah $45 \mathrm{~cm}$, dan panjang platform (F) alat material handling ini adalah $60 \mathrm{~cm}$. Ukuran ini dipertimbangkan berdasarkan lebar 1 sak semen yaitu sebesar $40 \mathrm{~cm}$, dan panjang $1 \mathrm{sak}$ semen yaitu sebesar $60 \mathrm{~cm}$.

Tinggi awal platform $(\mathrm{G})$ alat material handling ini adalah $65,5 \mathrm{~cm}$. Ukuran ini dipertimbangkan berdasarkan data antropometri tinggi genggaman tangan pada posisi relaks ke bawah pria (persentil 5). Hal ini bertujuan pada saat memindahkan semen dari mobil ke alat material handling, pekerja menemukan posisi yang tepat sehingga tidak perlu membungkuk. Penggunaan persentil 5 dimaksudkan agar orang dengan tinggi paling rendah dapat menggunakan alat ini dengan nyaman, sehingga secara tidak langsung orang yang lebih tinggi juga dapat menggunakannya dengan nyaman.
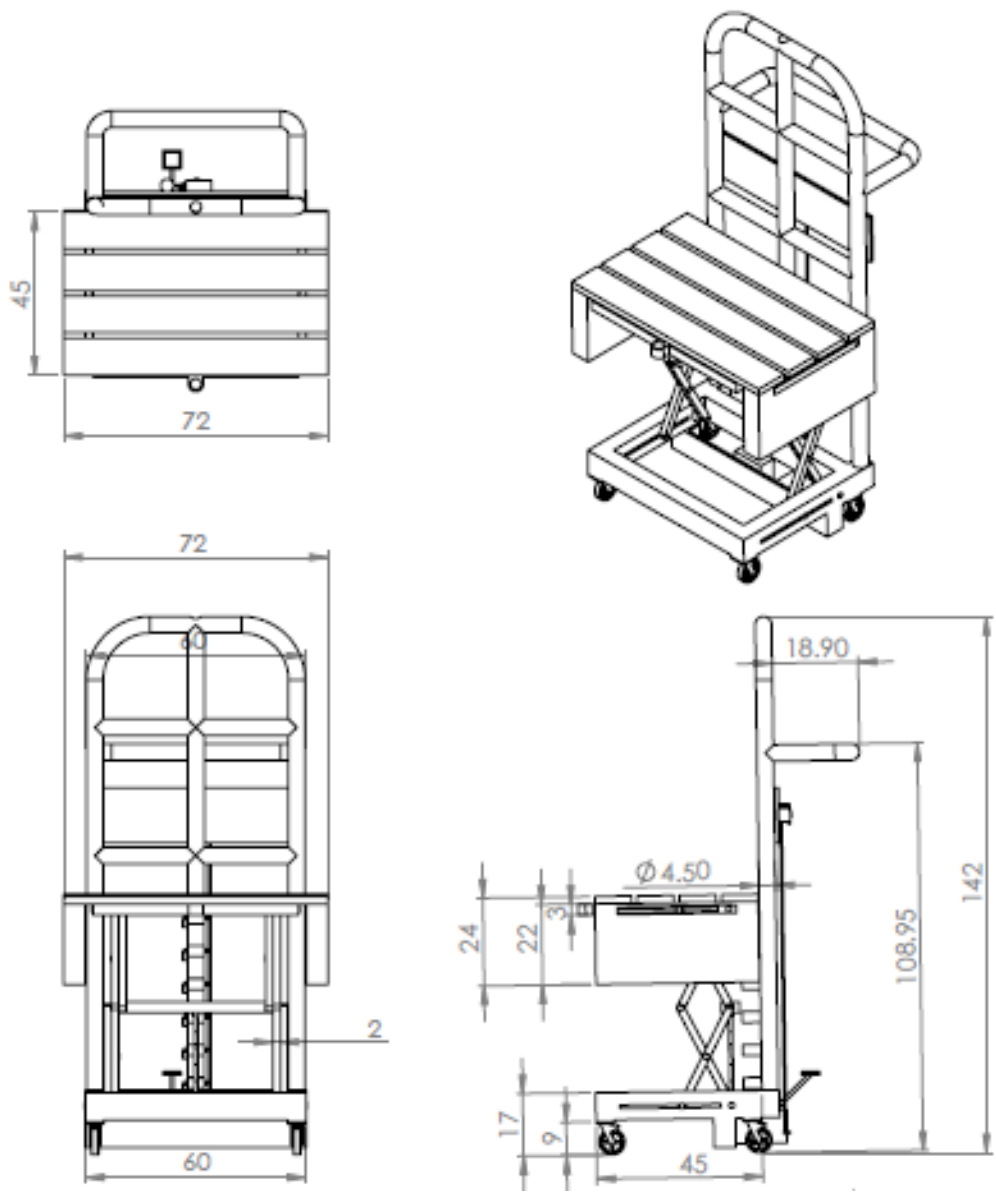

Gambar 8. Spesifikasi alat material handling usulan 
Untuk menaikkan meja ke atas, pekerja melakukan pemompaan pada injakan yang berada di bagiah belakang alat material handling ini (lihat gambar 9). Dengan melakukan pemompaan tersebut, perlahan-lahan meja akan terangkat ke atas dengan bantuan hidrolik tersebut. Kemudian pekerja dapat menaikan semen pada meja tersebut.

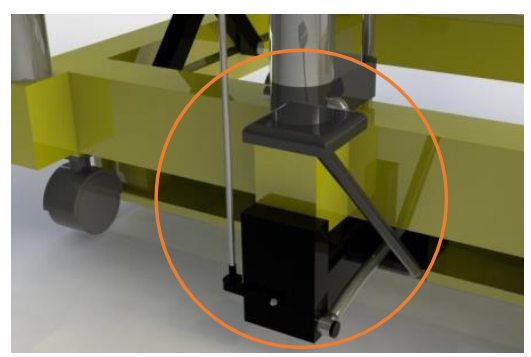

Gambar 9. Injakan untuk pemompaan

Untuk menurunkan meja, diperlukan beberapa tindakan. Hal ini dikarenakan terdapat tahanan yang akan memastikan bahwa hidrolik akan turun sejauh $9 \mathrm{~cm}$ setiap penekanan (lihat gambar 10).

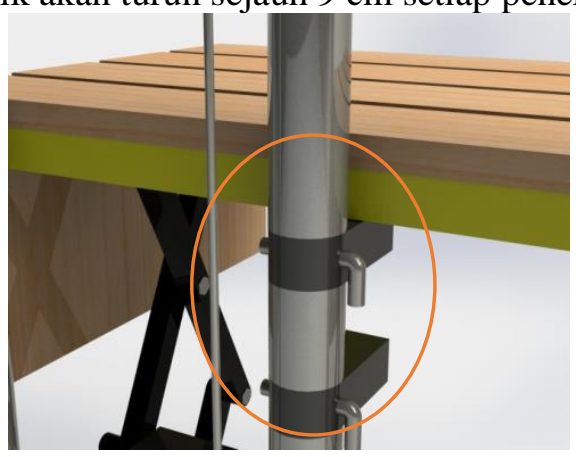

Gambar 10. Tahanan pallet

Penurunan sejauh $9 \mathrm{~cm}$ ini dinilai paling baik berdasarkan perhitungan berikut:

Tinggi awal meja hidrolik adalah $65,5 \mathrm{~cm}$, sehingga pada saat pekerja meletakkan semen tumpukan pertama di meja hidolik tersebut ketinggiannya adalah $65,5 \mathrm{~cm}$. Tinggi platformdan roda $17 \mathrm{~cm}$, dan tebal pallet $3 \mathrm{~cm}$, jarak antara lantai dengan ujung bawah pallet $0,5 \mathrm{~cm}$, sehingga besarnya sekali penurunan yang disarankan adalah sebagai berikut:

Keterangan:

$$
\begin{gathered}
65,5 \mathrm{~cm}-17 \mathrm{~cm}-3 \mathrm{~cm}-0,5 \mathrm{~cm}=5 \mathrm{x} \\
45 \mathrm{~cm}=5 \mathrm{x}, \text { sehingga } \mathrm{x}=9 \mathrm{~cm}
\end{gathered}
$$

5x yang dimaksudkan pada perhitungan diatas adalah jumlah penurunan meja hidrolik yang ada pada alat material handling ini, yang berarti sampai meja hidrolik tersebut menyentuh dasarnya, akan ada 5 sak semen yang ditumpuk pada alat tersebut. Hal ini dipertimbangkan berdasarkan postur tubuh pekerja aktual pada saat menaikkan semen yang sudah lebih baik pada saat tumpukan kelima. Punggung pekerja tidak membungkuk seperti pada saat meletakkan semen pada tumpukan bawah, sehingga diharapkan akan dapat mengurangi risiko cedera tulang belakang yang dialami pekerja.

Untuk menurunkan meja hidrolik tersebur pekerja perlu melepaskan kunci yang ada pada bagian penahan (lihat gambar 11), kemudian memutar kunci tersebut $180^{\circ}$ (ke arah sebaliknya) sehingga tidak terdapat penghalang jika ingin menurunkan meja hidrolik tersebut dan selanjutnya memasukkan kembali kunci tahanan tersebut pada bagian depan (lihat gambar 12). Penempatan kunci pada tahanan pada bagian depan ini dinilai lebih baik daripada memasangkannya kembali pada tempat semula dikarenakan pada saat memasangkan kunci tersebut pekerja tidak perlu menghabiskan terlalu banyak waktu untuk mengepaskan lubang yang ada pada tahanan dan pada 
handle. Selanjutnya pekerja hanya perlu menarik tuas yang berfungsi menurunkan meja hidrolik tersebut sampai ke tahanan selanjutnya yang berada dibawahnya (lihat gambar 13).

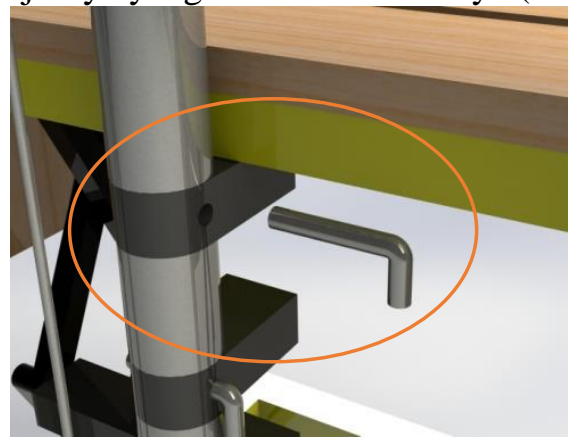

Gambar 11. Kunci pada tahanan

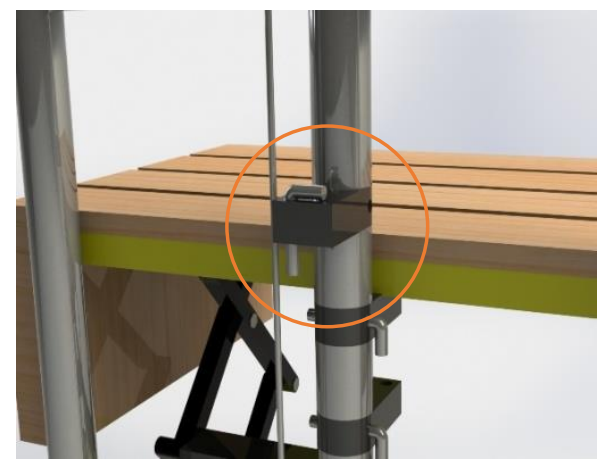

Gambar 12. Pemutaran tahanan

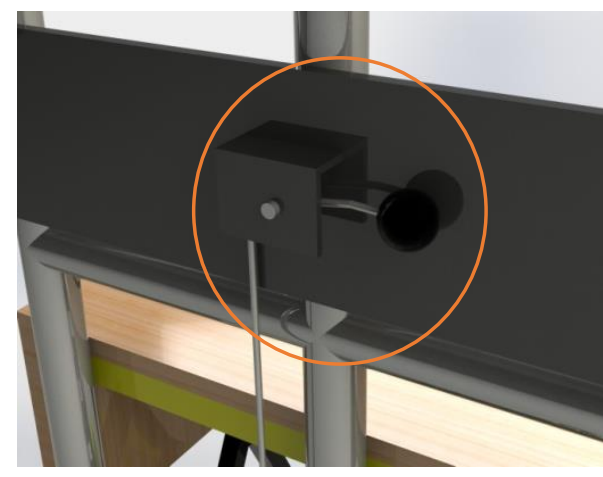

Gambar 13. Tuas untuk penurunan hidrolik

Dengan bantuan alat material handling ini, diharapkan dapat mengurangi risiko cedera tulang belakang yang dapat dialami oleh pekerja pada saat melakukan aktivitas pengangkatan semen. Hal ini dikarenakan dengan bantuan hidrolik, pekerja tidak perlu membungkuk pada saat meletakkan semen pada tumpukan bawah seperti yang biasa dilakukan sebelumnya. Alat material handling yang akan digunakan ini akan ditempatkan pada samping mobil sehingga pada saat pekerja melakukan pemindahan semen ke atasnya, pekerja hanya perlu mengangkat dan memindahkan semen pada alat tersebut dengan jarak yang relatif dekat, sehingga diharapkan tenaga yang dikeluarkan tidak terlalu besar dan pembebanan pada tubuh pekerja juga tidak terlalu lama.

Alat material handling yang akan digunakan ini akan ditempatkan pada samping mobil sehingga pada saat pekerja melakukan pemindahan semen ke atasnya, pekerja hanya perlu mengangkat dan memindahkan semen pada alat tersebut dengan jarak yang relatif dekat, sehingga diharapkan tenaga yang dikeluarkan tidak terlalu besar dan pembebanan pada tubuh pekerja juga tidak terlalu lama. 


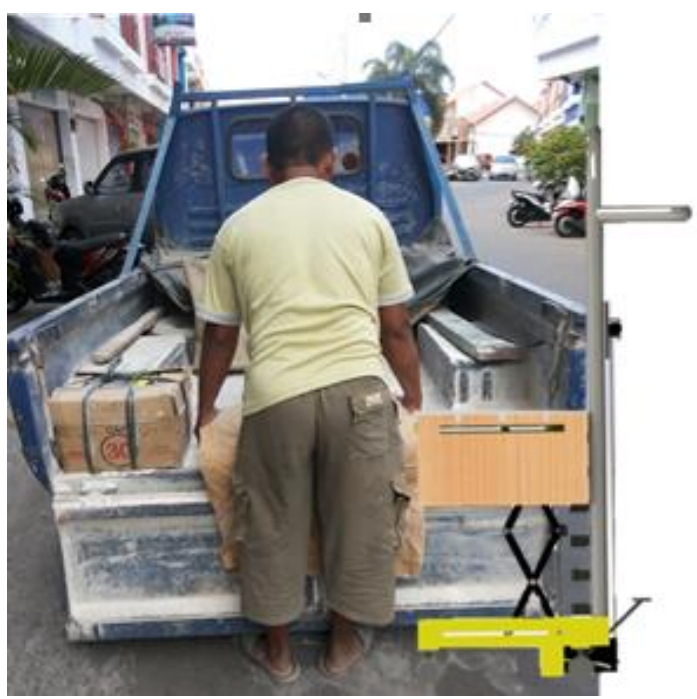

Gambar 14. Posisi alat material handling terhadap mobil

Selanjutnya pekerja akan meletakkan satu persatu semen dari dalam mobil ke atas pallet yang telah diletakkan pada meja yang ada pada alat material handling tersebut.Setelah pekerja melakukan pengangkatan dan peletakan semen sampai dengan tumpukan ke sepuluh, pekerja memasangkan pengunci pada bagian depan dan atas alat material handling tersebut. Pemasangan pengunci ini berfungsi sebagai penahan semen agar tidak terjatuh pada saat pendorongan alat tersebut ke dalam gudang. Setelah memasangkan pengunci yang memastikan semen tidak akan terjatuh ke depan pada saat pendorongan alat menuju gudang, pekerja dapat mendorong alat material handling tersebut ke dalam gudang.

Kemudian seperti yang telah dijelaskan sebelumnya, pekerja perlu melepaskan kunci tahanan, memutar tahanan, kemudian menarik tuas yang ada sehingga prinsip hidrolik digunakan dan meja dapat diturunkan. Hal ini berlangsung terus sampai pekerja meletakkan semen pada tumpukan kelima, dikarenakan batas turunnya meja hidrolik tersebut. Selanjutnya pekerja hanya perlu mengangkat dan meletakkan semen sampai dengan tumpukan sepuluh seperti biasa, tanpa perlu melepaskan kunci tahanan, memutar tahanan, serta menarik tuas tersebut lagi.

Setelah pekerja melakukan pengangkatan dan peletakan semen sampai dengan tumpukan kesepuluh, pekerja memasangkan pengunci berbahan dasar logam pada bagian depan (lihat gambar 15a) dan atas (lihat gambar 16) alat material handling tersebut. Pemasangan pengunci ini berfungsi sebagai penahan semen agar tidak terjatuh pada saat pendorongan alat tersebut kedalam gudang. Penggunaan pengunci dapat dilihat pada gambar 15 bagian a, tempat meletakkan pengunci pada saat trolley kosong dapat dilihat pada gambar 15 bagian $b$, dan posisi pengunci pada saat trolley kosong dapat dilihat pada gambar 15 bagian $\mathrm{c}$.
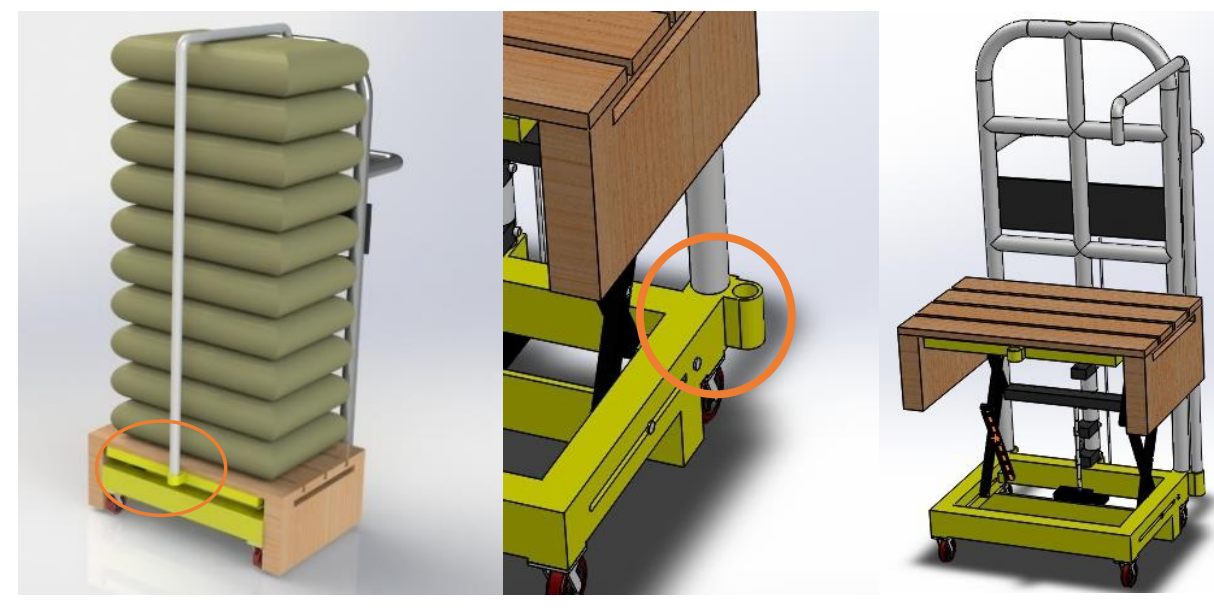

Gambar 15. Pengunci semen 


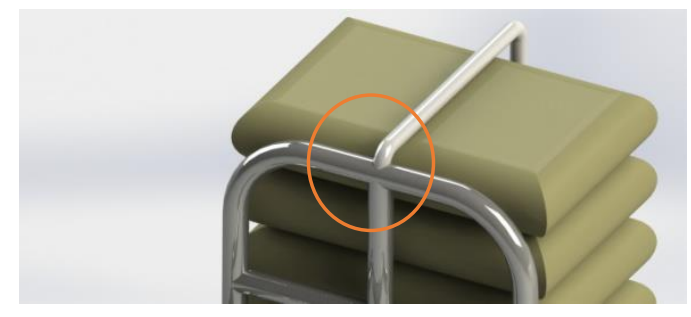

Gambar 16. Pemasangan pengunci pada bagian atas

Setelah memasangkan pengunci tersebut, pekerja dapat mendorong alat material handling tersebut ke dalam gudang. Setelah sampai di gudang, pekerja perlu memposisikan alat material handling tersebut di tempat yang disediakan, melepaskan pengunci semen, selanjutnya melepaskan kunci tahanan dan memutar tahanan yang terakhir, lalu menarik tuas yang ada tersebut sekali lagi, sehingga meja akan turun sedikit lagi yang akan menyebabkan kaki pallet menyentuh lantai dan terdapat sedikit jarak antara pallet dan meja pada alat material handling tersebut (lihat gambar 17). Dengan begitu, pekerja hanya perlu menarik kebelakang alat material handling tersebut dan membawanya ke luar gudang untuk diposisikan kembali terhadap mobil dan mengulangi proses tadi sampai semen yang harus diturunkan pada mobil tersebut habis.

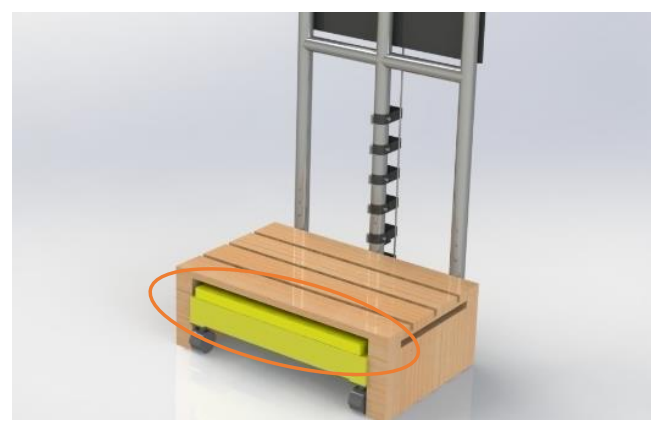

Gambar 17. Penurunan hidrolik terakhir

Pemindahan beban dengan mendorong lebih diutamakan (baik) daripada menarik, karena pekerja dapat melihat kondisi di depan. Gaya yang diperlukan untuk memindahkan beban menggunakan alat bantu adalah $2 \%$ dari beban total (berat 1 sak semen adalah $50 \mathrm{~kg}$, sehingga berat total adalah $500 \mathrm{~kg}$, maka gaya yang diperlukan setara beban $10 \mathrm{~kg}$ ). Batas gaya yang direkomendasikan oleh standar Health Safety Executive (2012) untuk menghentikan atau memulai suatu aktivitas bagi pria adalah $20 \mathrm{~kg}$, sedangkan batas gaya selama proses pemindahan adalah $10 \mathrm{~kg}$. Ditinjau dari rekomendasi Health Safety Executive tersebut, gaya yang diperlukan oleh pekerja masih memenuhi batas yang direkomendasikan, sehingga diharapkan tidak akan memberikan risiko cedera pada pekerja.

\subsection{Perhitungan REBA Usulan}

Setelah memberikan usulan alat bantu material handling, dilakukan penilaian risiko kembali cedera tulang belakang dengan menggunakan tools REBA guna mengetahui tingkat risiko yang baru. Pada tabel 5 dapat dilihat final score dan tingkat risiko usulan dari masing-masing skenario yang ada. Tingkat risiko rendah didapatkan pada hampir semua skenario yang ada, kecuali pada skenario 1 yang memiliki tingkat risiko menengah. Skenario 1 tidak bisa diubah dikarenakan pada skenario 1 ini merupakan pada saat pekerja mengangkat semen dari mobil, dan hal ini tidak dapat dilakukan perbaikan. 
Tabel 4. Perbandingan final score dan tingkat risiko sebelum dan setelah perbaikan

\begin{tabular}{|c|c|c|c|c|c|}
\hline \multirow{2}{*}{ Skenario } & \multirow{2}{*}{ Kegiatan } & \multicolumn{2}{|c|}{ Aktual } & \multicolumn{2}{c|}{ Usulan } \\
\cline { 3 - 6 } & & Final Score & $\begin{array}{c}\text { Tingkat } \\
\text { Risiko }\end{array}$ & Final Score & $\begin{array}{c}\text { Tingkat } \\
\text { Risiko }\end{array}$ \\
\hline 1 & Mengangkat semen dari mobil & 4 & Menengah & 4 & Menengah \\
\hline 2 & Berjalan dari mobil ke gudang & 3 & Rendah & 3 & Rendah \\
\hline 3 & Menurunkan semen tumpukan satu & 9 & Tinggi & 3 & Rendah \\
\hline 4 & Menurunkan semen tumpukan dua & 9 & Tinggi & 3 & Rendah \\
\hline 5 & Menurunkan semen tumpukan tiga & 9 & Tinggi & 3 & Rendah \\
\hline 6 & Menurunkan semen tumpukan empat & 9 & Tinggi & 3 & Rendah \\
\hline 7 & Menurunkan semen tumpukan lima & 5 & Menengah & 3 & Rendah \\
\hline 8 & Menurunkan semen tumpukan enam & 4 & Menengah & 3 & Rendah \\
\hline 9 & Menurunkan semen tumpukan tujuh & 4 & Menengah & 3 & Rendah \\
\hline 10 & Menurunkan semen tumpukan delapan & 3 & Rendah & 3 & Rendah \\
\hline 11 & Menurunkan semen tumpukan sembilan & 3 & Rendah & 3 & Rendah \\
\hline 12 & Menurunkan semen tumpukan sepuluh & 3 & Rendah & 3 & Rendah \\
\hline
\end{tabular}

\subsection{Perhitungan RWL Usulan}

Setelah melakukan pembuktian dengan metode REBA untuk membuktikan usulan yang diberikan menghasilkan final score dan tingkat risiko yang lebih baik, dilakukan juga pembuktian dengan perhitungan RWL dan lifting index terhadap usulan yang diberikan. Hasil yang didapatkan setelah perhitungan RWL dan lifting index dari aktivitas pengangkatan semen usulan ternyata masih ada yang cukup tinggi. Hal ini disebabkan karena berat beban yang harus diangkat oleh pekerja terlalu berat.

Tabel 5. Perbandingan RWL dan LI sebelum dan setelah perbaikan

\begin{tabular}{|c|c|c|c|c|c|c|c|c|}
\hline \multirow{2}{*}{ Skenario } & \multirow{2}{*}{ Kondisi } & \multicolumn{3}{|c|}{ aktual } & \multicolumn{3}{|c|}{ usulan } & \multirow{2}{*}{$\%$ Penurunan } \\
\hline & & RWL & LI & Keterangan & RWL & LI & Keterangan & \\
\hline \multirow{2}{*}{1} & Origin & 19.213 & \multirow{2}{*}{2.602} & \multirow{2}{*}{ mungkin berisiko } & 21.113 & \multirow{2}{*}{2.368} & \multirow{2}{*}{ mungkin berisiko } & \multirow{2}{*}{9} \\
\hline & Destination & 19.725 & & & 21.676 & & & \\
\hline \multirow{2}{*}{3} & Origin & 17.327 & \multirow{2}{*}{5.816} & \multirow{2}{*}{ berisiko } & 21.827 & \multirow{2}{*}{2.405} & \multirow{2}{*}{ mungkin berisiko } & \multirow{2}{*}{59} \\
\hline & Destination & 8.597 & & & 20.789 & & & \\
\hline \multirow{2}{*}{4} & Origin & 17.495 & \multirow{2}{*}{5.235} & \multirow{2}{*}{ berisiko } & 21.827 & \multirow{2}{*}{2.383} & \multirow{2}{*}{ mungkin berisiko } & \multirow{2}{*}{54} \\
\hline & Destination & 9.552 & & & 20.978 & & & \\
\hline \multirow{2}{*}{5} & Origin & 17.729 & \multirow{2}{*}{4.951} & \multirow{2}{*}{ berisiko } & 21.827 & \multirow{2}{*}{2.398} & \multirow{2}{*}{ mungkin berisiko } & \multirow{2}{*}{52} \\
\hline & Destination & 10.100 & & & 20.852 & & & \\
\hline \multirow{2}{*}{6} & Origin & 18.075 & \multirow{2}{*}{4.662} & \multirow{2}{*}{ berisiko } & 21.827 & \multirow{2}{*}{2.606} & munokin herisiko & 44 \\
\hline & Destination & 10.725 & & & 19.187 & & 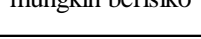 & 44 \\
\hline 7 & Origin & 18.639 & 334 & berisiko & 21.827 & 2447 & munokin berisiko & 44 \\
\hline & Destination & 11.502 & 4.541 & & 20.474 & 2.442 & & \\
\hline 8 & Origin & 19.725 & 3056 & hericiko & 21.827 & 721 & mungkin 1 & 31 \\
\hline 0 & Destination & 12.640 & 5.950 & DerisIKO & 18.309 & 2.731 & mungkin Derisiko & 31 \\
\hline 9 & Origin & 19.863 & 3857 & berisiko & 21.827 & & & 26 \\
\hline 9 & Destination & 12.964 & 5.857 & DerisiKo & 17.607 & 2.840 & mungkin Derisiko & 20 \\
\hline 10 & Origin & 19.863 & 3800 & hericiko & 21.470 & & mungkin hericike & 27 \\
\hline 10 & Destination & 13.150 & 5.002 & DenISIKO & 17.907 & 2.192 & 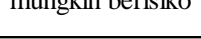 & 21 \\
\hline 11 & Origin & 19.863 & 4150 & herisiko & 20.385 & 2015 & munokin herisiko & 30 \\
\hline 11 & Destination & 12.022 & 4.159 & DenISIRO & 17.153 & 2.915 & 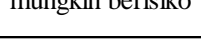 & 30 \\
\hline 12 & Origin & 19.863 & 4329 & berisiko & 19.805 & 3136 & berisiko & 28 \\
\hline & Destination & 11.551 & & & 15.943 & & & \\
\hline
\end{tabular}

Dari tabel diatas dapat dilihat terdapat penurunan nilai lifting index dari aktivitas pengangkatan semen yang dilakukan oleh pekerja dan masih adanya risiko cedera tulang belakang yang dapat dialami oleh pekerja tersebut dikarenakan terdapat beberapa faktor yang tidak mungkin dapat diusulkan oleh penulis karena berkaitan dengan supplier seperti berat beban serta coupling, serta kondisi seperti ketinggian semen yang beragam dan jarak horizontal dengan tubuh. Oleh sebab itu, 
usulan yang diberikan hanya terbatas pada penurunan/pengurangan nilai lifting index yang tidak terlalu signifikan.

\subsection{Analisis Gabungan}

Dari hasil perhitungan risiko cedera tulang belakang menggunakan metode REBA dan RWL, didapatkan rangkuman score aktual dan usulan dari masing-masing metode seperti yang dapat dilihat pada tabel berikut ini.

Tabel 6. Rangkuman score aktual dan usulan masing-masing metode

\begin{tabular}{|c|c|c|c|c|c|c|c|c|}
\hline \multirow{3}{*}{ skenario } & \multicolumn{4}{|c|}{ REBA } & \multicolumn{4}{|c|}{ RWL } \\
\hline & \multicolumn{2}{|c|}{ aktual } & \multicolumn{2}{|c|}{ usulan } & \multicolumn{2}{|c|}{ aktual } & \multicolumn{2}{|c|}{ usulan } \\
\hline & final score & keterangan & final score & keterangan & lifting index & keterangan & lifting index & keterangan \\
\hline 1 & 4 & risiko menengah & 4 & risiko menengah & \begin{tabular}{|l|}
2.602 \\
\end{tabular} & mungkin berisiko & 2.368 & mungkin berisiko \\
\hline 3 & 9 & risiko tinggi & 3 & risiko rendah & 5.816 & berisiko & 2.405 & mungkin berisiko \\
\hline 4 & 9 & risiko tinggi & 3 & risiko rendah & 5.235 & berisiko & 2.383 & mungkin berisiko \\
\hline 7 & 5 & risiko menengah & 3 & risiko rendah & 4.347 & berisiko & 2.442 & mungkin berisiko \\
\hline 8 & 4 & risiko menengah & 3 & risiko rendah & 3.956 & berisiko & 2.731 & mungkin berisiko \\
\hline 9 & 4 & risiko menengah & 3 & risiko rendah & 3.857 & berisiko & 2.840 & mungkin berisiko \\
\hline 10 & 3 & risiko rendah & 3 & risiko rendah & 3.802 & berisiko & 2.792 & mungkin berisiko \\
\hline 11 & 3 & risiko rendah & 3 & risiko rendah & 4.159 & berisiko & 2.915 & mungkin berisiko \\
\hline
\end{tabular}

Dari metode REBA terlihat penurunan risiko cedera tulang belakang yang cukup signifikan. Tidak ada lagi tingkat risiko tinggi yang dialami oleh pekerja. Risiko menengah juga hanya terlihat pada skenario 1 dimana itu merupakan kondisi yang tidak dapat diubah lagi karena merupakan kondisi pada saat pekerja mengangkat semen dari mobil.

Dari metode RWL terlihat beberapa penurunan risiko cedera tulang belakang yang dialami oleh pekerja. Masih adanya nilai lifting index diatas 3 tersebut hanya terjadi di skenario 12 saja. Hal ini dikarenakan terdapat beberapa faktor yang tidak dapat diperbaiki terkait dengan desain dari sak semen maupun kondisi di lapangan. Oleh karena itu, penulis menyarankan pada saat memindahkan semen dengan menggunakan alat bantu material handling pekerja hanya menumpukkannya sampai dengan tumpukan ke 9 saja. Hal ini dikarenakan apabila pekerja menumpuk sampai dengan tumpukkan ke 10 (skenario 12) maka berisiko cedera tulang belakang ditinjau dari metode RWL yang telah dibuktikan sebelumnya.

Selain ditinjau dari penurunan tingkat risiko cedera tulang belakang yang dihasilkan oleh metode REBA dan RWL, penggunaan alat bantu material handling ini juga akan mengurangi tingkat kelelahan pekerja. Jika tadinya dari kuesioner SOFI diketahui pekerja mengalami kelelahan fisik diakibatkan karena sekali perjalanan dari mobil ke gudang hanya bisa memindahkan 1 sak semen saja, sekarang bisa memindahkan 9 sak semen sekaligus. Selain itu jarak pengangkatan yang tadinya dari mobil menuju ke gudang juga sudah berkurang, karena pengangkatan sekarang hanya dari mobil ke alat material handling yang diletakkan dekat dengan mobil. Beban total dalam sekali pemindahan yaitu $450 \mathrm{~kg}$ juga dianggap tidak bermasalah, dikarenakan alat material handling tersebut dilengkapi dengan roda di keempat sisinya sehingga proses pemindahan barang menjadi lebih ringan. Selain itu jalan yang dilalui dari mobil ke gudang juga merupakan jalan yang rata dan tidak terdapat lubang yang dapat mengakibatkan kesulitan pada saat mendorong alat tersebut.

Dari kuesioner nordic body map awal diketahui bahwa pekerja merasakan kelelahan pada beberapa bagian tubuhnya. Rasa sakit pada bagian punggung dan pinggang pekerja diperkirakan terjadi karena pada saat menurunkan semen pada tumpukan bawah, punggung pekerja perlu membungkuk. Hal ini terjadi terus secara berulang sehingga rasa sakit yang dialami pekerja merupakan akumulasi dari aktivitas yang dilakukannya tersebut. Rasa sakit pada bagian tangan, lengan, maupun kaki pekerja diperkirakan terjadi karena pekerja harus mengangkat dan menahan berat semen tersebut 
dari mobil menuju ke gudang. Dengan adanya alat bantu material handling ini, pekerja tidak perlu lagi membungkuk pada saat menurunkan semen pada tumpukan bawah, juga jarak pemindahan semen dari mobil menuju alat material handling yang cukup dekat sehingga durasi pekerja menahan berat semen tersebut sudah jauh berkurang.

Oleh sebab itu, usulan yang diberikan oleh penulis dinilai sudah cukup dalam mengurangi risiko cedera tulang belakang pada aktivitas pemindahan semen di Toko Bangunan X ini.

\section{Kesimpulan dan Saran}

\subsection{Kesimpulan}

Berdasarkan pengolahan data dan analisis yang telah dilakukan maka penulis menarik beberapa kesimpulan, yaitu:

1. Berdasarkan kuesioner SOFI diketahui bahwa pekerja merasakan ketidaknyamanan fisik, kurang energi, dan kelelahan fisik setelah melakukan aktivitas pengangkatan semen. Ketidaknyamanan fisik, kurang energi, dan kelelahan fisik dialami pekerja setelah melakukan aktivitas pengangkatan 50 sak maupun 100 sak semen. Seiring dengan banyaknya sak semen yang diangkat pekerja, maka tingkat keluhan pekerja juga semakin meningkat.

2. Berdasarkan hasil kuesioner nordic body map diketahui bahwa pekerja merasa kurang nyaman atau sakit pada beberapa bagian tubuh setelah melakukan aktivitas pengangkatan semen. Pada saat pekerja telah mengangkat 50 sak semen, pekerja tersebut merasa sakit pada bagian lengan atas kanan, lengan atas kiri, punggung, dan pinggang. Setelah pekerja mengangkat 100 sak semen, keluhan sakit pada bagian tubuh pekerja menjadi bertambah yakni pekerja merasa sakit pada bagian leher bagian atas, leher bagian bawah, bahu kanan, bahu kiri, lengan atas kanan, lengan atas kiri, lengan bawah kanan, lengan bawah kiri, pergelangan tangan kanan, pergelangan tangan kiri, tangan kanan, tangan kiri, paha kanan, paha kiri, betis kanan, betis kiri, serta kaki kanan dan kaki kiri. Keluhan sangat sakit dirasakan pekerja pada bagian punggung dan pinggang pekerja.

3. Kondisi postur pekerja saat ini ditinjau dari segi analisis metode REBA (Rapid Entire Body Assesment) terlihat bahwa dari 12 skenario yang disimulasikan oleh penulis terdapat 4 skenario yang memiliki tingkat risiko tinggi (skenario 3, skenario 4, skenario 5, dan skenario 6), 4 skenario memiliki tigkat risiko menengah (skenario 1, skenario 7, skenario 8, dan skenario 9), dan 4 skenario memiliki tingkat risiko rendah (skenario 2, skenario 10, skenario 11 , dan skenario 12).

4. Berdasarkan perhitungan RWL dan LI ternyata aktivitas pengangkatan semen ini dapat menimbulkan risiko musculoskeletal disorders. Hal ini terjadi karena berat beban yang cukup berat, serta masing-masing faktor penentu RWL yang kurang baik.

5. Perbaikan dilakukan dengan mengusulkan alat bantu material handling yang disesuaikan dengan kebutuhan pekerja. Penulis memberikan usulan alat material handling berupa hand trolley yang dapat mereduksi tingkat risiko cedera tulang belakang pada aktivitas pengangkatan semen ini. Hand trolley tersebut menggunakan bantuan hidrolik, dilengkapi dengan pengunci roda, pengaman pada tumpukan semen, dan dapat membawa 10 sak semen sekaligus. Penentuan ukuran dan dimensi alat material handling disesuaikan dengan dimensi barang yang diangkut, serta data antropometri. Hal ini bertujuan agar pekerja dapat melakukannya dengan aman, nyaman, dan tepat.

6. Setelah melakukan perbaikan, dilakukan penilaian kembali dengan menggunakan metode REBA yang dapat dilihat pada tabel 6.1. Final score REBA usulan yang didapatkan mengalami penurunan, yang berarti bahwa usulan yang diberikan dapat mengatasi masalah musculoskeletal disorders yang dapat dialami oleh pekerja. Perbandingan final score dan tingkat risiko sebelum dan setelah perbaikan dapat dilihat pada tabel 6.2. Hasil dari REBA usulan tersebut menyatakan bahwa dari 12 skenario yang ada hanya terdapat 1 skenario dengan tingkat risiko menengah dan 11 skenario sisanya dengan tingkat risiko rendah.

7. Setelah melakukan perbaikan, dilakukan penilaian kembali dengan menggunakan RWL dan LI. Nilai lifting index usulan sudah mengalami penurunan secara signifikan. 


\subsection{Saran}

Berdasarkan hasil pengolahan data dan analisis serta kesimpulan yang telah dibuat oleh penulis, maka penulis memberikan saran baik untuk pihak perusahaan maupun untuk penelitian selanjutnya, yaitu sebagai berikut:

1. Mengimplementasikan usulan alat bantu material handling agar pekerja dapat terhindar dari risiko terjadinya musculoskeletal disorders.

2. Melakukan kembali penyebaran kuesioner SOFI dan Nordic Body Map untuk kondisi kerja yang baru untuk memastikan keluhan pekerja terkait aktivitas yang dilakukan.

3. Menganalisis kembali faktor-faktor yang dapat menyebabkan risiko terjadinya musculoskeletal disorders pada pekerja yang melakukan aktivitas pengangkatan barang berat.

4. Meneliti faktor risiko individu seperti status kesehatan, tingkat gizi, dan faktor risiko lingkungan seperti suhu, getaran, dan cahaya.

5. Pada penelitian perancangan alat bantu material handling ini tidak memperhitungkan kekuatan bahan dan aspek biaya, sehingga hal yang berkaitan dengan kekuatan bahan dan aspek biaya alat bantu material handling ini dapat digunakan pada penelitian selanjutnya.

\section{Daftar Pustaka}

Ahmadi A., Mirzaei R., and Ansari H. (2015), "Assessment of Work Postures and Prevalence Of Musculoskeletal Disorders Among Porcelain Industry Workers", Journal of Occupational Health and Epidemiology (JOHE) Volume 4 Issue 3 pp.146-153

Ahsberg, E. (1998), "Perceived Fatigue Related to Work", National Institute for Working Life.

Ansari, N. A. and Sheikh, M. J. (2014), "Evaluation of work Posture by RULA and REBA: A Case Study", IOSR Journal of Mechanical and Civil Engineering (IOSRJMCE) e-ISSN: 2278-1684,pISSN: 2320-334X, Volume 11, Issue 4 Ver. III, pp 18-23

Chaffin, Don B. (2006), “Occupational Biomechanic”, New York: John Wiley \& Sons.

Evita, Sarvia E. (2017), "Perbaikan Postur Kerja pada Operator Stasiun Two for One Bawah Menggunakan Metode REBA", Jurnal Sains, Teknologi dan Industri, Vol. 14, No.2, Juni 2017, pp.199- 208.

Evita, Sarvia E. (2019), "Perbaikan Postur Kerja pada Operator Stasiun Two for One Bawah Menggunakan Metode REBA", Journal of Integrated System, Vol. 2, No.1, Juli 2019, pp.37- 50.

Hignett, S., \& McAtamney, L. (2000), "Rapid Entire Body Assessment (REBA"), Applied Ergonomics, 31(2), 201-205.

Ingale, P. A., \& Salunke, P. V. (2016), "Rapid Entire Body and Rapid Upper Limb Assessment Of Operator For Multipurpose Wheel Lathe Machine", International Journal of Mechanical Engineering and Information Technology, 4(3), 1636-1641.

Iridiastadi, Hardianto.; “Ergonomi : Suatu Pengantar”, PT Remaja Rosdakarya Offset, 2014.

I Rizkya* , K Syahputri, R M Sari, Anizar, I Siregar, "Evaluation of work posture and quantification of fatigue by Rapid Entire Body Assessment (REBA)", IOP Conference Series: Materials Science and Engineering, 2018. doi:10.1088/1757-899X/309/1/012051

Halim, I. and Omar, A. R. (2011), "A Review On Health Effects Associated With Prolonged Standing In The Industrial Workplaces", International Journal of Research and Review in Applied Science Volume 8 Issue 1.

Nurmianto, Eko (2004), “Ergonomi: Konsep Dasar dan Aplikasinya”, ITS Surabaya. 
PERANCANGAN ALAT MATERIAL HANDLING (Lydia L.K., dkk.)

Srikanth P., Chakravarthya1, Subbaiah, K. M., and Shekar, G. L. (2015), "Ergonomic Assessment And Risk Reduction Of Automobile Assembly Tasks Using Postural Assessment Tools", International Journal of Research Science \& Management.

Suhardi, Bambang (2008), "Perancangan Sistem Kerja dan Ergonomi Industri Jilid 2. Departemen Penidikan Nasional”. Jakarta: Departemen Pendidikan RI.

Suma'mur (1989), "Ergonomi Untuk Kesehatan dan Keselamatan Kerja, dan Produktivitas", Surakarta : UNIBA Press.

S. H. Tarwaka and L. Sudiajeng (2004), "Ergonomi Untuk Keselamatan, Kesehatan Kerja Dan Produktivitas", Surakarta: UNIBA. 